\title{
Repairing Hybrid Mg-Al-Mg Components Using Sustainable Cooling Systems
}

\author{
David Blanco $^{1,+} \mathbb{B}$, Eva María Rubio ${ }^{1, * \mathbb{C}}$, Marta María Marín ${ }^{1}$ and Joao Paulo Davim ${ }^{2}$ \\ 1 Department of Manufacturing Engineering, Industrial Engineering School, Universidad Nacional de \\ Educación a Distancia (UNED), St/Juan del Rosal 12, E28040 Madrid, Spain; \\ dblanco78@alumno.uned.es (D.B.); mmarin@ind.uned.es (M.M.M.) \\ 2 Department of Mechanical Engineering, University of Aveiro, 3810-193 Aveiro, Portugal; pdavim@ua.pt \\ * Correspondence: erubio@ind.uned.es; Tel.: +34-913-988-226 \\ † Programa de Doctorado en Tecnologías Industriales.
}

Received: 5 December 2019; Accepted: 13 January 2020; Published: 15 January 2020

\begin{abstract}
This paper focused on the maintenance or repair of holes made using hybrid $\mathrm{Mg}-\mathrm{Al}-\mathrm{Mg}$ components by drilling, using two sustainable cooling techniques (dry machining and cold compressed air) and taking surface roughness on the inside of the holes as the response variable. The novelty of the work is in proving that the repair operations of the multi-material components (magnesium-aluminum-magnesium) and the parts made of aluminum and magnesium (separately) but assembled to form a higher component can be done simultaneously, thus reducing the time and cost of the assembly and disassembly of this type of component. The study is based on a design of experiments (DOE) defined as a product of a full factorial $2^{3}$ and a block of two factors $(3 \times 2)$. Based on our findings, we propose that the analyzed operations are feasible under sustainable conditions and, in particular, under dry machining. Also, the results depend on the machining order.
\end{abstract}

Keywords: hybrid components; light alloys; magnesium; aluminum; drilling; dry machining; cold compressed air; lubrication and cooling systems; arithmetical mean roughness; $R a$; average maximum height; $R z$; repair and maintenance operations

\section{Introduction}

Today, energy efficiency and sustainability play an increasingly important role in the development of new materials and their applications, especially in the transport industry, due to the pollution generated by the vehicles or their different parts in many stages of their life cycle.

Therefore, in order to reduce such contamination, it is necessary to approach the problem in a global way, analyzing all the factors that can have an influence during the manufacturing, the use, the maintenance, the repair, and the recycling of each part.

Although new forms of energy are being investigated to propel vehicles, these new alternative energies need to be greatly improved to match the level of development achieved with fossil fuels.

Until these new kinds of sustainable energy become competitive, in the transport sector, it is still essential to decrease the weight of vehicles to reduce the quantity of fossil fuels used, and, as a consequence, the pollution associated with its consumption. This is particularly true for the aeronautic and aerospace sectors.

To achieve this goal, research focuses on the use of the combination of different materials to create new multi-material components with better global properties than those of the original individual materials. These materials are called hybrid components, and the number of studies associated with them grew exponentially in recent years. Rubio and collaborators [1] affirmed that, among the possible combinations of materials used to form hybrid components with structural uses, the metal-polymer 
and metal-metal combinations are two of the most used, with aluminum alloys being most used to form these types of hybrid materials. Some of the main applications of these combination materials in the automotive sectors are car sleeper roofs, door structures, car fronts, tubular components of the exhaust system, and tubular components of the suspension system. In the aeronautic sector, the main applications are in the fuselage of airplanes and helicopters, the wings and rotors, and the other control surfaces (ailerons, flaps, spoilers, aerodynamic brakes, slats, and horizontal and vertical stabilizers).

The use of lightweight structural materials is widespread in various industries, particularly the aeronautics and automotive industries, since the weight of aircraft and cars is directly related to their consumption and pollution. A $10 \%$ reduction in the weight of an automobile can lead to improvements in fuel efficiency (by $8 \%$ ), acceleration, and braking performance, and can reduce $\mathrm{CO}$ and hydrocarbon (HC) emissions by $4.5 \%$, and NOx emissions by $8.8 \%$ [2]. In the civil aircraft industry, the weight of a Boeing 747-400 is approximately $183,500 \mathrm{~kg}$, and the estimated fuel savings for an airplane is, over short distances, 117-134 kg of kerosene per kilogram of reduced weight and, over long distances, $172-212 \mathrm{~kg}$ of kerosene per kilogram of reduced weight [3].

Within the industries mentioned above, light alloys are used widely thanks to their excellent weight/mechanical strength ratio. Also, in recent years, combinations of light alloys (hybrid components) began to be used. Among them, it is possible to highlight the combination of aluminum and magnesium alloys. Both types of alloys can be combined with each other or with other lightweight and resistant materials to create hybrid materials, thereby extending the boundaries of the material's property space [4-8]. Also, magnesium and aluminum present other interesting advantages in relation to sustainability; for example, both are easy to recycle $[9,10]$.

Regarding magnesium, several recycling options exist. Firstly, when the scrap is of sufficient quality, it can be reprocessed to obtain parts with good specifications. Secondly, magnesium scrap can be used to produce other metallic materials. Finally, magnesium can be recycled for use as a raw material in the production of fertilizers [11].

Aluminum has $95 \%$ recyclability at the end of its useful life. Also, recycling saves $95 \%$ of the energy used in its initial production. Moreover, according to the Environmental Product Declarations (EPD), it was shown that aluminum contains an average of $39 \%$ recycled aluminum and $61 \%$ primary aluminum. In addition to its recyclability, aluminum has an excellent carbon footprint. The EPD states that, for its different types (anodized and lacquered, with and without a thermal break), the values of $\mathrm{CO}_{2}$ range between 10.3 and $11.8 \mathrm{~kg}$ of $\mathrm{CO}_{2}$ per $\mathrm{kg}$ of aluminum, and recycling can achieve exemptions of between 3.0 and $4.0 \mathrm{~kg}$ of $\mathrm{CO}_{2}$ per $\mathrm{kg}$ of aluminum.

The primary non-renewable energy used in the manufacture of aluminum products is another indicator of the impact they generate. As with the previous rate, considering all aluminum types included in the EPD, the primary energy is $420 \mathrm{MJ}$ and $324 \mathrm{MJ}$ per $\mathrm{kg}$ of aluminum. Therefore, aluminum recycling provides energy savings of between 49 and $38 \mathrm{MJ}$ [9].

On the other hand, the geometric, dimensional shape and surface requirements are very strict in the aeronautics or aerospace sectors, which makes these parts types expensive and sometimes difficult or even impossible to keep stock of them ready for when it is necessary to maintain or repair damaged parts. Therefore, it is important to guarantee that it is possible to carry out efficient and sustainable repair or maintenance operations, thereby extending the lifetime of these parts and improving sustainability [12-14].

As the density of magnesium $\left(1740 \mathrm{~kg} / \mathrm{m}^{3}\right)$ is the lowest among structural metals (being two-thirds that of aluminum and one-quarter that of steel), its alloys are interesting candidates for combination with heavier alloys to reduce weight. However, magnesium has low machinability and high flammability (especially as powder or chips). In fact, the magnesium flame temperature and its alloys can reach 3100 ${ }^{\circ} \mathrm{C}$ and, once the fire starts, it is difficult to extinguish since there is continuous combustion of nitrogen, carbon dioxide, and water [15]. Also, molten magnesium reacts violently with water. For these reasons, it is necessary to study the behavior of magnesium when it is mechanized along with other materials (forming hybrid components), testing if such combinations are suitable for manufacturing, repair, and 
maintenance. For example, steel produces sparks during machining at cutting speeds between 200 to $300 \mathrm{~m} / \mathrm{min}$ [16], and this can be extremely dangerous if magnesium is present.

Therefore, when magnesium-containing hybrid components are going to be mechanized, it is necessary to take certain security measures regarding the lubricants or coolant systems employed. Depending on the material or materials with which magnesium is combined, different lubrication/cooling techniques can be used [17,18] both individually (dry machining [19-31], minimum quantity lubrication (MQL) [30-42], solid lubrication [43-47], cryogenic cooling [48-55], gaseous cooling [56-61], nanofluids [62-66], and sustainable cutting fluids [67-72]) and in combination [73-76]. Some of these techniques were tested in several previous works with the intention of better describing the behavior of the individual materials (especially aluminum [19-23], titanium [30,31,39], and magnesium [16,28,77-104]). From the point of view of the optimization of the costs of the process and its sustainability, the ideal would be (1) to be able to completely eliminate lubricants or coolants and carry out dry machining, (2) to test more recently developed techniques (such as machining with minimum quantity of lubricant, cold compressed air or cryogenic refrigerants), and (3) to develop new lubricants or refrigerants compatible with magnesium.

The machining of this type of hybrid component results in an increase in process instability due to the different properties of the materials that form them and their particular cutting characteristics [12]. This makes it necessary to determine the best cutting parameters for each combination of materials, especially when strict design requirements must be reached. Although the literature contains an important number of experimental works with regard the machining of hybrid components, only some of them addressed hybrid components based on magnesium. Most studies focused on machining processes [105-113] and tried to find the optimal combination of machining conditions and lubrication/cooling systems by means of experimental tests, taking the surface roughness required in a particular industry sector or application as a response variable. Others dealt with friction and wear between contact materials $[114,115]$, the effects of pre-treatments on the adhesion of hybrid materials [116], innovative techniques for forming these types of components [117,118], or identification of some of the most prominent issues.

The scope of this work is to prove that repair and maintenance operations can fix holes made in pieces of hybrid components based on magnesium and aluminum, not only in an efficient way, but also sustainably. Therefore, considering the above, this experimental study focused on the drilling of hybrid Mg-Al-Mg components. For decades, aluminum and magnesium were used (separately) in the aeronautical sector due to their good weight/mechanical properties. Thus, given that the density of magnesium is two-thirds that of aluminum, it was hypothesized that they could be used together, reducing weight by replacing aluminum with magnesium where possible.

The drilling process is used regularly in this sector and, thus, it was well analyzed; for only the assembly of the wing to the fuselage, thousands of holes are required $[119,120]$.

The repair and maintenance operations were selected as they represent an additional challenge versus those of manufacturing, since, as previously mentioned, the lack of parts in aeronautical stock means having to do the repair in the shortest possible time to reduce the costs associated with the downtime of the aircraft. Also, two cooling systems (dry machining and cold compressed air) were tested to analyze the sustainability of the process. Surface roughness was chosen as a response variable as it is one of the most widespread in the literature, thereby allowing a better contrast of the results obtained; the required values for the sector are also standardized $(0.8 \mu \mathrm{m}<R a<1.6 \mu \mathrm{m})$ [121].

The novelty of the work is in proving that the repair operations of multi-material components (magnesium-aluminum-magnesium) and the parts made of aluminum and magnesium (separately) but assembled to form a higher component can be repaired simultaneously. This approach saves time and reduces cost. 


\section{Methodology}

As this work is part of a broader research project that involves different geometries, material combinations, cutting conditions, tools, and lubrication/cooling systems, the methodology is similar to that followed in other previous works [105-108] and is based on the guidelines given by Montgomery [122].

\subsection{Pre-Experimental Planning}

Here, we report the findings of an experimental study addressing the repair or maintenance of holes made in parts of Mg-Al-Mg hybrid components using sustainable cooling systems. The study focuses on the aeronautical sector. As the response variable, we chose surface roughness since it is commonly used as a reference of quality in aeronautical components and is also used to evaluate the efficiency of the machining processes; thus, there are several works in the literature with which to make comparisons.

To determine the factors, levels, and range of their values, it should be noted that these are repair operations; hence, the depth of cut must be as small as possible to maintain the dimensional design requirements. On the other hand, since these are two non-ferrous alloys with similar machinability characteristics, it would be sufficient to test a unique type of tool. Moreover, since two cooling systems (dry machining and cold compressed air) were tested, and only a single pre-drilled part with eight holes through the $\mathrm{Mg}-\mathrm{Al}-\mathrm{Mg}$ combination was available, it was necessary to adapt the remaining factors and levels to the number of holes. Therefore, we decided to use the feed rate and the spindle speed (and two levels for each) as factors.

Additionally, as it was thought that the surface of the drilled holes could be damaged, not only by the cutting process but also due to friction caused by the chips inside of them (due to the accumulation along the mechanized length), and seeing that a similar factor was taken into account in other works [19-26], it was decided to include two additional factors related to the location relative to the insert (with three levels, one for each one of the stacks: $\mathrm{Mg}-\mathrm{Al}-\mathrm{Mg}$ ) and related to the location relative to the specimen, that is, each hole (with two levels, one at the entry of the holes and one at the exit holes), where measurement of the surface roughness was taken.

\subsection{Experimental Design}

Considering everything explained in the pre-experimental planning, the depth of cut and the type of tool do not affect the design of experiments (DOE) since they only have one level. For the feed rate, $f$ $(\mathrm{mm} / \mathrm{rev})$, the spindle speed, $N(\mathrm{rpm})$, and the type of cooling system, $C$, two levels were taken for each, i.e., $(f 1, f 2),(N 1, N 2)$, and $(C 1, C 2)$, respectively. In the same way, for the additional factors where the surface roughness was measured, i.e., location relative to the insert, $L R I$, and location relative to the specimen, LRS, three (LRI1, LRI2, LRI3) and two (LRS1, LRS2) levels were taken, respectively. Table 1 describes the factors and levels selected for this experimental analysis.

Table 1. Factors and levels.

\begin{tabular}{cc}
\hline Factors & Levels \\
\hline Feed rate, $f(\mathrm{~mm} / \mathrm{rev})$ & $f 1, f 2$ \\
Spindle speed, $N(\mathrm{rpm})$ & $N 1, N 2$ \\
Type of cooling system, $C$ & $C 1, C 2$ \\
Location relative to the insert, $L R I$ & LRI1, LRI2, LRI3 \\
Location relative to the specimen, $L R S$ & LRS1, LRS2 \\
\hline
\end{tabular}

The surface roughness was taken as the response variable, and the average roughness values $(R a)$ and the average maximum height $(R z)$ were measured in the different zones defined by the factors location relative to the insert $(L R I)$ and location relative to the specimen $(L R S)$. The factors and levels 
are shown in Table 1 , and a DOE, as a product of a full factorial $2^{3}$ and a block of two factors $(3 \times 2)$, was defined with a total of eight experimental re-drills and 24 measurements of the surface roughness, which provided a total of 48 values ( 24 of $R a$ and 24 of $R z$ ). Also, the design was randomized to reduce the influence of non-considered variables [122] (Table 2).

Table 2. Experimental design: product of a full factorial $2^{3}$ and a block of two factors $(3 \times 2)$.

\begin{tabular}{|c|c|c|c|c|c|c|c|c|c|c|c|c|c|c|c|c|c|}
\hline No. & $f^{*}$ & $N^{* *}$ & $C$ & LRI & LRS & No & $f^{*}$ & $N^{* *}$ & $C$ & $L R I$ & LRS & No. & $f^{*}$ & $N^{* *}$ & $C$ & $L R I$ & LRS \\
\hline 1 & $f 1$ & N1 & $C 1$ & LRI1 & LRS1 & 1 & $f 1$ & N1 & C1 & LRI2 & LRS1 & 1 & $f 1$ & N1 & $C 1$ & LRI3 & LRS1 \\
\hline 1 & $f 1$ & N1 & $C 1$ & LRI1 & LRS2 & 1 & $f 1$ & N1 & $C 1$ & LRI2 & LRS2 & 1 & $f 1$ & N1 & $C 1$ & LRI3 & LRS2 \\
\hline 2 & $f 1$ & N2 & $C 1$ & LRI1 & LRS1 & 2 & $f 1$ & N2 & $C 1$ & LRI2 & LRS1 & 2 & $f 1$ & N2 & $C 1$ & LRI3 & LRS1 \\
\hline 2 & $f 1$ & N2 & C1 & LRI1 & LRS2 & 2 & $f 1$ & N2 & C1 & LRI2 & LRS2 & 2 & $f 1$ & N2 & C1 & LRI3 & LRS2 \\
\hline 3 & $f 2$ & N1 & C1 & LRI1 & LRS1 & 3 & $f 2$ & N1 & C1 & LRI2 & LRS1 & 3 & $f 2$ & N1 & C1 & LRI3 & LRS1 \\
\hline 3 & $f 2$ & N1 & C1 & LRI1 & LRS2 & 3 & $f 2$ & N1 & C1 & LRI2 & LRS2 & 3 & $f 2$ & N1 & C1 & LRI3 & LRS2 \\
\hline 4 & $f 2$ & N2 & $C 1$ & LRI1 & LRS1 & 4 & $f 2$ & N2 & $C 1$ & LRI2 & LRS1 & 4 & $f 2$ & N2 & $C 1$ & LRI3 & LRS1 \\
\hline 4 & $f 2$ & N2 & $C 1$ & LRI1 & LRS2 & 4 & $f 2$ & N2 & $C 1$ & LRI2 & LRS2 & 4 & $f 2$ & N2 & $C 1$ & LRI3 & LRS2 \\
\hline 5 & $f 1$ & N1 & C2 & LRI1 & LRS1 & 5 & $f 1$ & N1 & C2 & LRI2 & LRS1 & 5 & $f 1$ & N1 & C2 & LRI3 & LRS1 \\
\hline 5 & $f 1$ & N1 & C2 & LRI1 & LRS2 & 5 & $f 1$ & N1 & C2 & LRI2 & LRS2 & 5 & $f 1$ & N1 & C2 & LRI3 & LRS2 \\
\hline 6 & $f 1$ & N2 & C2 & LRI1 & LRS1 & 6 & $f 1$ & N2 & C2 & LRI2 & LRS1 & 6 & $f 1$ & N2 & C2 & LRI3 & LRS1 \\
\hline 6 & $f 1$ & N2 & C2 & LRI1 & LRS2 & 6 & $f 1$ & N2 & C2 & LRI2 & LRS2 & 6 & $f 1$ & N2 & C2 & LRI3 & LRS2 \\
\hline 7 & $f 2$ & N1 & C2 & LRI1 & LRS1 & 7 & $f 2$ & N1 & C2 & LRI2 & LRS1 & 7 & $f 2$ & N1 & C2 & LRI3 & LRS1 \\
\hline 7 & $f 2$ & N1 & $C 2$ & LRI1 & LRS2 & 7 & $f 2$ & N1 & C2 & LRI2 & LRS2 & 7 & $f 2$ & N1 & C2 & LRI3 & LRS2 \\
\hline 8 & $f 2$ & N2 & C2 & LRI1 & LRS1 & 8 & $f 2$ & N2 & C2 & LRI2 & LRS1 & 8 & $f 2$ & N2 & C2 & LRI3 & LRS1 \\
\hline 8 & $f 2$ & N2 & C2 & LRI1 & LRS2 & 8 & $f 2$ & N2 & C2 & LRI2 & LRS2 & 8 & $f 2$ & N2 & C2 & LRI3 & LRS2 \\
\hline
\end{tabular}

\subsection{Performing the Experiment}

Before carrying out the re-drilling tests, it was necessary to collect the specimens of the hybrid parts, the tools, and the cooling systems, as well as introduce the parameter values into the machine tools and establish cutting conditions and data collecting protocols. Next, the machining operations were carried out and, finally, photographs and videos of the trials were taken for subsequent analysis.

\subsection{Statistical Analysis of the Data}

Once the machining process was finished, the arithmetical mean roughness $(R a)$ and average maximum height $(R z)$ were measured. The data were statistically analyzed, including an analysis of variance (ANOVA) to identify the influential factors for surface roughness variation and the interactions among them.

\subsection{Conclusions}

The main conclusions extracted from the descriptive analysis of the obtained results and their statistical analysis were established.

\section{Applications and Results}

\subsection{Materials}

The hybrid component specimen was made of three parallelepiped plates of dimensions $50 \times 50$ $\times 15 \mathrm{~mm}$ pre-drilled with eight holes of $8 \mathrm{~mm}$ in diameter. The three plates were mechanically fixed so that they could be easily disassembled to take the measurements inside the holes. The plates placed above and below were of magnesium alloy (UNS M11917), and the other (placed between them) was of aluminum alloy (UNS A92024). The chemical composition of both materials is given in Table 3. 
Table 3. Chemical composition of the materials used for the manufacturing specimens.

\begin{tabular}{cc}
\hline UNS M11917 (AZ91D) & UNS A92024 (AA2024 T351) \\
\hline $\mathrm{Al} 8.30-9.70 \%$ & $\mathrm{Al} 90.7-94.7 \%$ \\
$\mathrm{Cu} \leq 0.03 \%$ & $\mathrm{Cr} \leq 0.1 \%$ \\
$\mathrm{Fe} \leq 0.005 \%$ & $\mathrm{Cu} 3.8-4.9 \%$ \\
$\mathrm{Mg} 90 \%$ & $\mathrm{Fe} \leq 0.5 \%$ \\
$\mathrm{Mn} \geq 0.13 \%$ & $\mathrm{Mg} 1.2-1.8 \%$ \\
$\mathrm{Ni} \leq 0.002 \%$ & $\mathrm{Mn} 0.3-0.9 \%$ \\
$\mathrm{Si} \leq 0.1 \%$ & $\mathrm{Si} \leq 0.5 \%$ \\
$\mathrm{Zn} 0.35-1 \%$ & $\mathrm{Ti} \leq 0.15 \%$ \\
- & $\mathrm{Zn} \leq 0.25 \%$ \\
\hline
\end{tabular}

These materials were selected because the authors had previous experience in their machining, both independently [12-14,16-23,25,28-32,77-79,82-94] and together [105-108]. Also, there were interesting works of other researchers in the literature, thus allowing comparisons to be drawn $[15,24,26,27,80,81,95-104]$.

\subsection{Tools}

As the target of this study was to analyze the feasibility of carrying out the repair and maintenance operations in an efficient and sustainable way, a single level for the depth of cut factor, $d$, was taken ( $d=0.5 \mathrm{~mm}$, using of a 9-mm-diameter drill bit). On the other hand, keeping the depth of cut at a low level also helps to keep the cutting temperature low and, therefore, to keep the magnesium temperature far from its ignition temperature.

The tools used in the trials were helical drill bits of high performance. They were made of a high-speed-steel (known as Cobalt Steel, HSSE, or HSS-E), obtained by powder metallurgy (PM) (Figure 1). The tools, with reference HSS-E-PM A1 1257, were purchased from Garant (Hoffmann Iberia, San Fernando de Henares, Madrid, Spain).

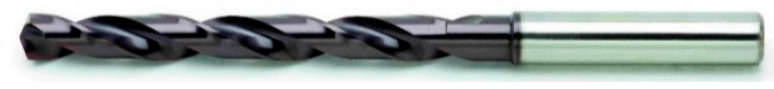

Figure 1. Helical drill bits HSS-E-PM A1 1257 manufactured by Garant [123].

Their dimensions were $9 \mathrm{~mm}$ of diameter, $81 \mathrm{~mm}$ of helical length, and $131 \mathrm{~mm}$ of total length. In addition, their special geometry allowed self-centering and optimal chip evacuation.

\subsection{Machines and Equipment}

The trials were carried out in a Tongtai TMV510 machining center (Tongai Machine \&Tool Co., Luzhu Dist, Kaohsiung City, Taiwan) equipped with a Control Numeric Computer (CNC) Fanuc (Fanuc Iberia, Castelldefels, Barcelona, Spain) (Figure 2a). A drilling cycle was programmed that made the tool penetrate $10 \mathrm{~mm}$, and then return to evacuate the generated chips. The same sequence was repeated until the tool crossed the entire width of the piece formed by the three stacks of $\mathrm{Mg}-\mathrm{Al}-\mathrm{Mg}$. This was done so that the accumulated chips inside the holes did not scratch the surface or stop or hinder the tool inside the piece. Cold compressed air (CCA) was used as the cooling system, implementing a Vortec Cold Air Gun (Vortec, Cincinnati, Ohio, USA) (Figure 2b). The roughness measurements were taken using a Mitutoyo Surftest SJ 401 roughness tester (Figure 2c) with the following settings: measuring range, $800 \mu \mathrm{m}$; resolution, $0.000125 \mu \mathrm{m}$; transverse length, $25 \mathrm{~mm}$; cut off, $0.8 \mathrm{~mm}$; scan rate, $4 \mathrm{~mm}(N=5)$; the standard ISO 1997 [124] was used. 


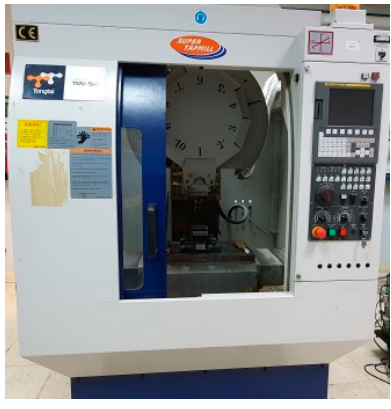

(a)

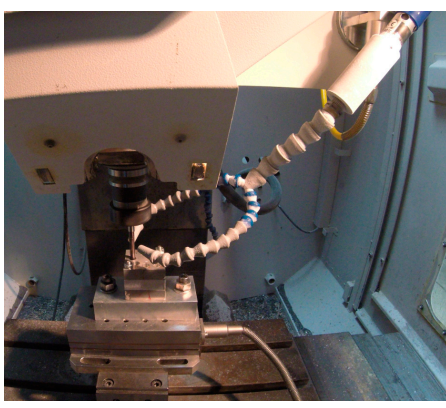

(b)

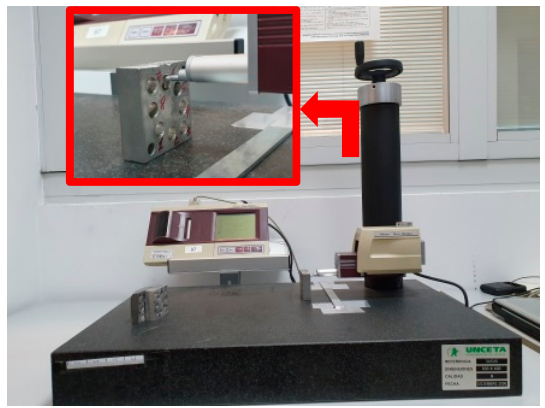

(c)

Figure 2. (a) Tongtai TMV510 machining center; (b) details of the Vortec Cold Air Gun during the trials; (c) Mitutoyo Surftest SJ 401 roughness tester.

\subsection{Experimental Tests}

The design of experiments, the materials, tools, machines, and equipment used in the trials, and the parameter value ranges are given in Table 4.

Table 4. Factors, levels, and values. CCA—cold compressed air.

\begin{tabular}{cc}
\hline Factors & Level Values \\
\hline Feed rate, $f(\mathrm{~mm} / \mathrm{rev})$ & $f 1=0.05 ; f 2=0.10$ \\
Spindle speed, $N(\mathrm{rpm})$ & $N 1=500 ; N 2=1200$ \\
Type of cooling system, $C$ & $C 1=\mathrm{CCA} C 2=\mathrm{dry}$ \\
Location relative to the insert, $L R I$ & $L R I 1=\mathrm{Mg} ; L R I 2=\mathrm{Al} ; L R I 3=\mathrm{Mg}$ \\
Location relative to the specimen, $L R S$ & $L R S 1=$ specimen entry zone; $L R S 2=$ specimen exit zone \\
\hline
\end{tabular}

The locations of the measurement zones of the surface roughness are shown in Figure 3. LRI1 denotes the first magnesium plate, LRI2 denotes the aluminum plate, and LRI3 denotes the second (and last) magnesium plate. LRS took into account the location of the measuring zone inside each hole after re-drilling it, and its levels were defined as LRS1 (the specimen entry zone) and LRS2 (the specimen exit zone). Figure 4 provides a graphical summary of the experimental set-up.

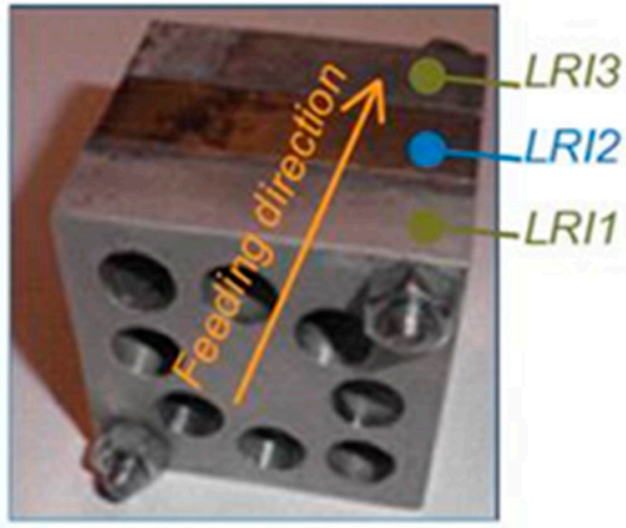

(a)

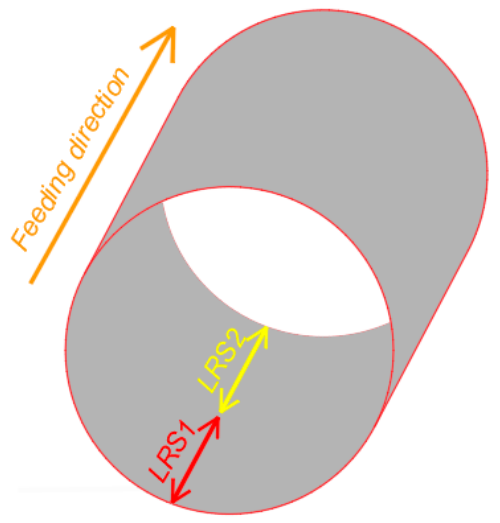

(b)

Figure 3. The concrete locations of the measurement zones of the surface roughness: (a) location relative to the insert, LRI; (b) location relative to the specimen, LRS. 


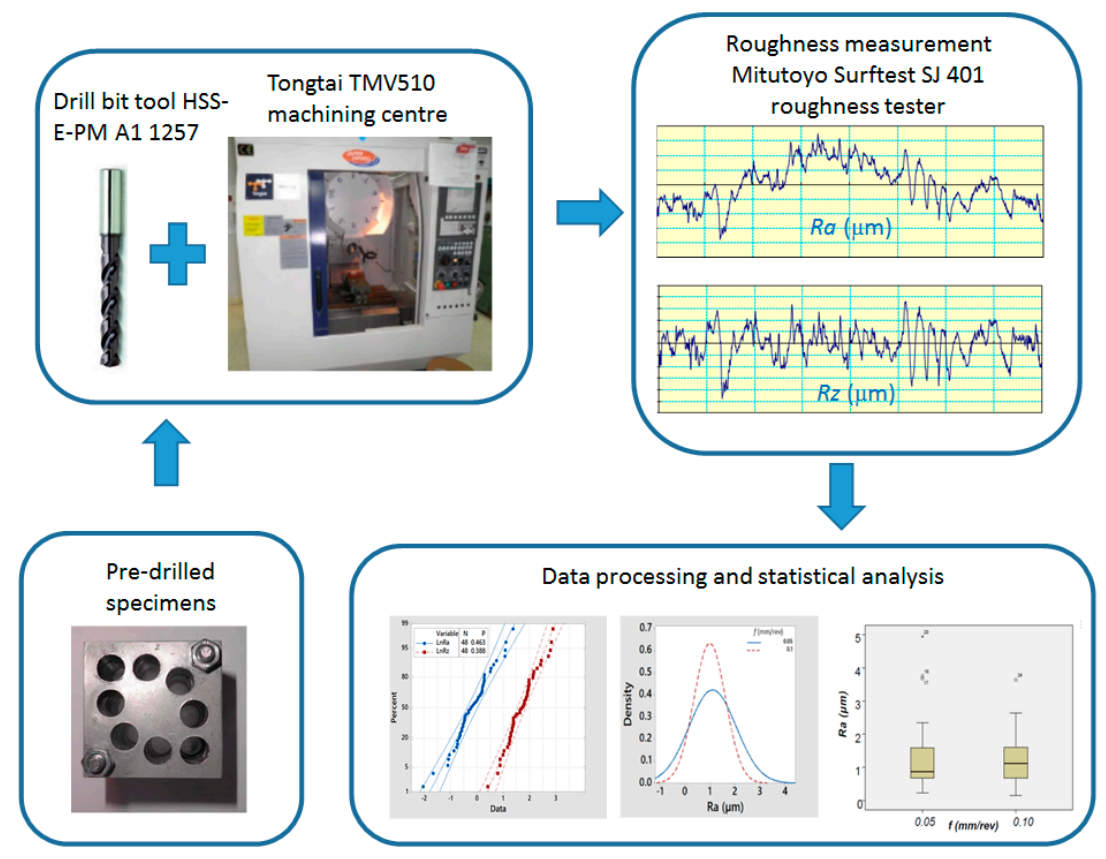

Figure 4. The experimental set-up.

\subsection{Analysis and Discussion of the Results}

After performing the eight re-drilling tests, surface roughness measurements were made in each hole in the three plates (entry and exit zones). The values of the arithmetical mean roughness $(R a)$ and the average maximum height $(R z)$ were calculated (in micrometers) and are given in Table 5.

Table 5. The arithmetical mean roughness $(R a)$ and the average maximum height $(R z)$ obtained during the measurement tests.

\begin{tabular}{cccccccc}
\hline No. & $\boldsymbol{f}(\mathbf{m m} / \mathbf{r e v})$ & $\boldsymbol{N}(\mathbf{r p m})$ & $\boldsymbol{C}$ & LRI & LRS & $\boldsymbol{R a}(\boldsymbol{\mu m})$ & $\boldsymbol{R z}(\boldsymbol{\mu m})$ \\
\hline 1 & 0.05 & 500 & $C C A$ & LRI1 & LRS1 & 0.35 & 2.70 \\
1 & 0.05 & 500 & CCA & LRI1 & LRS2 & 0.81 & 4.30 \\
2 & 0.05 & 1200 & CCA & LRI1 & LRS1 & 1.06 & 6.10 \\
2 & 0.05 & 1200 & CCA & LRI1 & LRS2 & 1.23 & 7.20 \\
3 & 0.10 & 500 & CCA & LRI1 & LRS1 & 1.27 & 8.50 \\
3 & 0.10 & 500 & CCA & LRI1 & LRS2 & 1.31 & 7.00 \\
4 & 0.10 & 1200 & CCA & LRI1 & LRS1 & 1.03 & 6.40 \\
4 & 0.10 & 1200 & CCA & LRI1 & LRS2 & 1.33 & 7.20 \\
5 & 0.05 & 500 & Dry & LRI1 & LRS1 & 1.22 & 6.90 \\
5 & 0.05 & 500 & Dry & LRI1 & LRS2 & 0.19 & 2.20 \\
6 & 0.05 & 1200 & Dry & LRI1 & LRS1 & 0.61 & 4.60 \\
6 & 0.05 & 1200 & Dry & LRI1 & LRS2 & 0.73 & 5.70 \\
7 & 0.10 & 500 & Dry & LRI1 & LRS1 & 0.73 & 5.40 \\
7 & 0.10 & 500 & Dry & LRI1 & LRS2 & 0.48 & 3.60 \\
8 & 0.10 & 1200 & Dry & LRI1 & LRS1 & 0.98 & 7.00 \\
8 & 0.10 & 1200 & Dry & LRI1 & LRS2 & 0.62 & 4.00 \\
1 & 0.05 & 500 & CCA & LRI2 & LRS1 & 2.94 & 16.80 \\
1 & 0.05 & 500 & CCA & LRI2 & LRS2 & 3.00 & 16.20 \\
\hline
\end{tabular}


Table 5. Cont.

\begin{tabular}{|c|c|c|c|c|c|c|c|}
\hline No. & $f(\mathrm{~mm} / \mathrm{rev})$ & $N$ (rpm) & $C$ & $L R I$ & LRS & $R a(\mu \mathrm{m})$ & $R z(\mu \mathrm{m})$ \\
\hline 2 & 0.05 & 1200 & $C C A$ & LRI2 & LRS1 & 1.31 & 7.20 \\
\hline 2 & 0.05 & 1200 & $C C A$ & LRI2 & LRS2 & 3.95 & 18.00 \\
\hline 3 & 0.10 & 500 & $C C A$ & LRI2 & LRS1 & 1.20 & 8.70 \\
\hline 3 & 0.10 & 500 & $C C A$ & LRI2 & LRS2 & 2.11 & 11.50 \\
\hline 4 & 0.10 & 1200 & $C C A$ & LRI2 & LRS1 & 0.13 & 1.50 \\
\hline 4 & 0.10 & 1200 & $C C A$ & LRI2 & LRS2 & 2.91 & 15.20 \\
\hline 5 & 0.05 & 500 & Dry & LRI2 & LRS1 & 1.24 & 6.80 \\
\hline 5 & 0.05 & 500 & Dry & LRI2 & LRS2 & 1.30 & 6.80 \\
\hline 6 & 0.05 & 1200 & Dry & LRI2 & LRS1 & 1.88 & 11.20 \\
\hline 6 & 0.05 & 1200 & Dry & LRI2 & LRS2 & 0.51 & 4.00 \\
\hline 7 & 0.10 & 500 & Dry & LRI2 & LRS1 & 0.87 & 5.10 \\
\hline 7 & 0.10 & 500 & Dry & LRI2 & LRS2 & 0.33 & 2.40 \\
\hline 8 & 0.10 & 1200 & Dry & LRI2 & LRS1 & 1.66 & 8.40 \\
\hline 8 & 0.10 & 1200 & Dry & LRI2 & LRS2 & 1.70 & 9.80 \\
\hline 1 & 0.05 & 500 & $C C A$ & LRI3 & LRS1 & 0.48 & 4.00 \\
\hline 1 & 0.05 & 500 & $C C A$ & LRI3 & LRS2 & 0.59 & 3.40 \\
\hline 2 & 0.05 & 1200 & $C C A$ & LRI3 & LRS1 & 0.64 & 4.00 \\
\hline 2 & 0.05 & 1200 & $C C A$ & LRI3 & LRS2 & 0.56 & 3.50 \\
\hline 3 & 0.10 & 500 & $C C A$ & LRI3 & LRS1 & 0.56 & 3.20 \\
\hline 3 & 0.10 & 500 & $C C A$ & LRI3 & LRS2 & 0.78 & 5.10 \\
\hline 4 & 0.10 & 1200 & $C C A$ & LRI3 & LRS1 & 1.13 & 6.10 \\
\hline 4 & 0.10 & 1200 & $C C A$ & LRI3 & LRS2 & 0.92 & 5.90 \\
\hline 5 & 0.05 & 500 & Dry & LRI3 & LRS1 & 0.34 & 2.40 \\
\hline 5 & 0.05 & 500 & Dry & LRI3 & LRS2 & 0.67 & 6.50 \\
\hline 6 & 0.05 & 1200 & Dry & LRI3 & LRS1 & 0.53 & 3.50 \\
\hline 6 & 0.05 & 1200 & Dry & LRI3 & LRS2 & 0.63 & 3.80 \\
\hline 7 & 0.10 & 500 & Dry & LRI3 & LRS1 & 0.46 & 2.80 \\
\hline 7 & 0.10 & 500 & Dry & LRI3 & LRS2 & 0.42 & 3.60 \\
\hline 8 & 0.10 & 1200 & Dry & LRI3 & LRS1 & 0.59 & 3.80 \\
\hline 8 & 0.10 & 1200 & Dry & LRI3 & LRS2 & 0.53 & 3.90 \\
\hline
\end{tabular}

Initially, a descriptive method was used to analyze the $R a$ and $R z$ values. The obtained results are separated into Tables 6 and 7. Tables 6 and 7 give the values of $R a$ and $R z$, respectively, in each plate (both in the entry and exit zones of the holes).

Table 6. Values of $R a$ in each plate at the entry and at the exit zones of the holes.

\begin{tabular}{|c|c|c|c|c|c|c|c|c|c|}
\hline \multirow{3}{*}{ No. } & \multirow{3}{*}{$F(\mathrm{~mm} / \mathrm{rev})$} & \multirow{3}{*}{$N(r p m)$} & \multirow{3}{*}{ C } & \multicolumn{6}{|c|}{$R a(\mu \mathrm{m})$} \\
\hline & & & & \multicolumn{2}{|c|}{ LRI1 } & \multicolumn{2}{|c|}{ LRI2 } & \multicolumn{2}{|c|}{ LRI3 } \\
\hline & & & & LRS1 & LRS2 & LRS1 & LRS2 & LRS1 & LRS2 \\
\hline 1 & 0.05 & 500 & $C C A$ & 0.35 & 0.81 & 2.94 & 3.00 & 0.48 & 0.59 \\
\hline 2 & 0.05 & 1200 & $C C A$ & 1.06 & 1.23 & 1.31 & 3.95 & 0.64 & 0.56 \\
\hline 3 & 0.10 & 500 & $C C A$ & 1.27 & 1.31 & 1.20 & 2.11 & 0.56 & 0.78 \\
\hline 4 & 0.10 & 1200 & $C C A$ & 1.03 & 1.33 & 0.13 & 2.91 & 1.13 & 0.92 \\
\hline 5 & 0.05 & 500 & Dry & 1.22 & 0.19 & 1.24 & 1.30 & 0.34 & 0.67 \\
\hline 6 & 0.05 & 1200 & Dry & 0.61 & 0.73 & 1.88 & 0.51 & 0.53 & 0.63 \\
\hline 7 & 0.10 & 500 & Dry & 0.73 & 0.48 & 0.87 & 0.33 & 0.46 & 0.42 \\
\hline 8 & 0.10 & 1200 & Dry & 0.98 & 0.62 & 1.66 & 1.70 & 0.59 & 0.53 \\
\hline
\end{tabular}


Table 7. Values of $R z$ in each plate at the entry and exit zones of the holes.

\begin{tabular}{|c|c|c|c|c|c|c|c|c|c|}
\hline \multirow{3}{*}{ No. } & \multirow{3}{*}{$F(\mathrm{~mm} / \mathrm{rev})$} & \multirow{3}{*}{$N(r p m)$} & \multirow{3}{*}{ C } & \multicolumn{6}{|c|}{$R z(\mu \mathrm{m})$} \\
\hline & & & & \multicolumn{2}{|c|}{ LRI1 } & \multicolumn{2}{|c|}{ LRI2 } & \multicolumn{2}{|c|}{ LRI3 } \\
\hline & & & & LRS1 & LRS2 & LRS1 & LRS2 & LRS1 & LRS2 \\
\hline 1 & 0.05 & 500 & $C C A$ & 2.70 & 4.30 & 16.80 & 16.20 & 4.00 & 3.40 \\
\hline 2 & 0.05 & 1200 & $C C A$ & 6.10 & 7.20 & 7.20 & 18.00 & 4.00 & 3.50 \\
\hline 3 & 0.10 & 500 & $C C A$ & 8.50 & 7.00 & 8.70 & 11.50 & 3.20 & 5.10 \\
\hline 4 & 0.10 & 1200 & $C C A$ & 6.40 & 7.20 & 1.50 & 15.20 & 6.10 & 5.90 \\
\hline 5 & 0.05 & 500 & Dry & 6.90 & 2.20 & 6.80 & 6.80 & 2.40 & 6.50 \\
\hline 6 & 0.05 & 1200 & Dry & 4.60 & 5.70 & 11.20 & 4.00 & 3.50 & 3.80 \\
\hline 7 & 0.10 & 500 & Dry & 5.40 & 3.60 & 5.10 & 2.40 & 2.80 & 3.60 \\
\hline 8 & 0.10 & 1200 & Dry & 7.00 & 4.00 & 8.40 & 9.80 & 3.80 & 3.90 \\
\hline
\end{tabular}

From the $R a$ and $R z$ values given in Tables 6 and 7, the graphics of Figure 5 were drawn. Figure 5 shows the normal distribution of $R a$ (left column) and $R z$ (right column) with respect to feed rate, $f$ (mm/rev), (a) $R a$ and (b) $R z$; spindle speed, $N$ (rpm), (c) $R a$ and (d) $R z$; type of cooling system, $C$, (e) $R a$ and (f) $R z$; location relative to the insert, $L R I,(\mathrm{~g}) R a$ and (h) $R z$; and location relative to the specimen, $L R S$, (i) $R a$ and (j) $R z$.

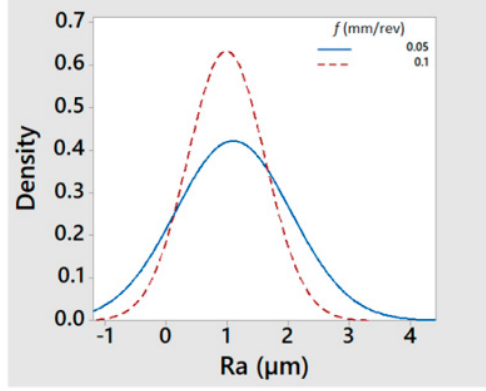

(a)

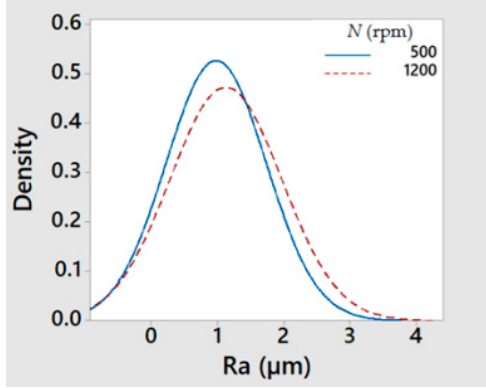

(c)

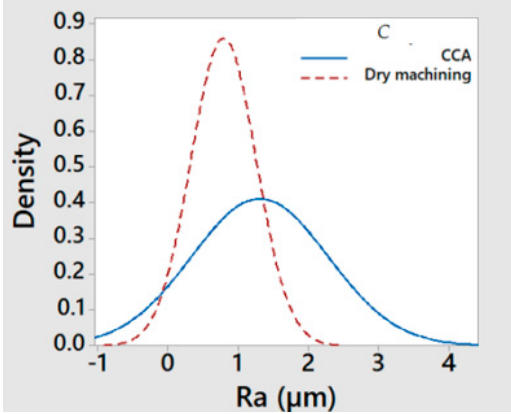

(e)

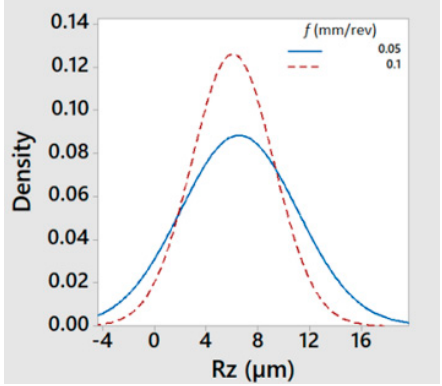

(b)

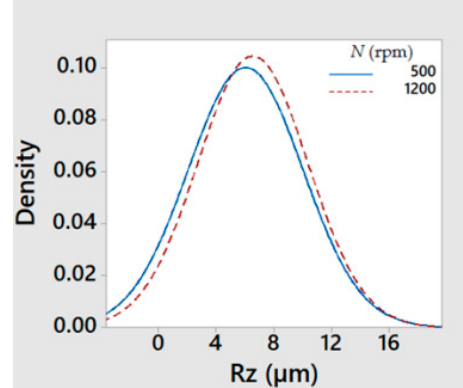

(d)

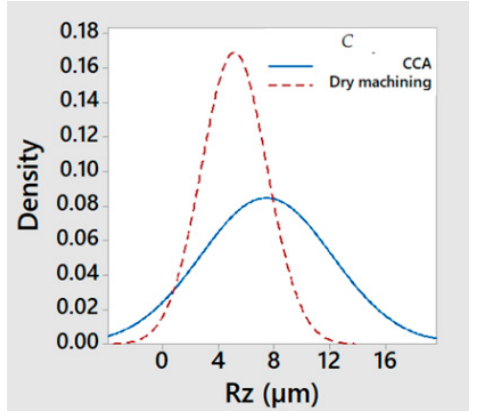

(f)

Figure 5. Cont. 


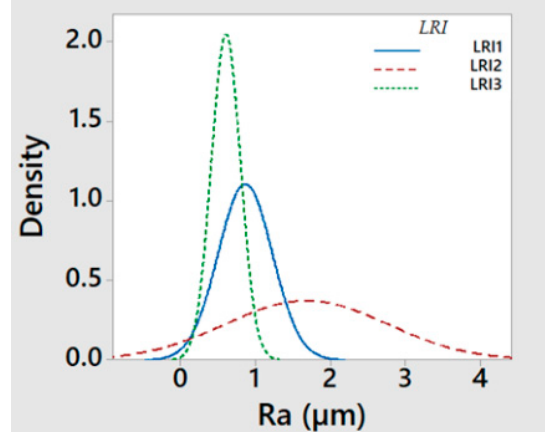

(g)

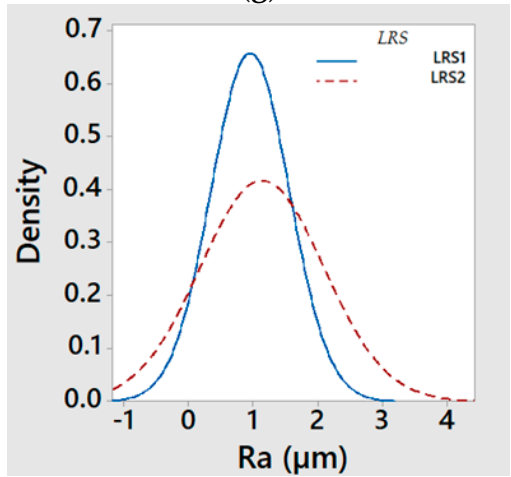

(i)

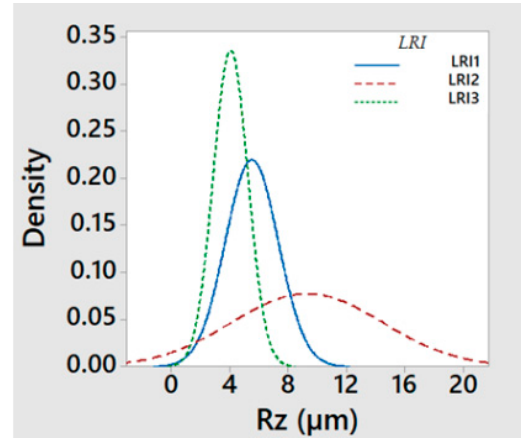

(h)

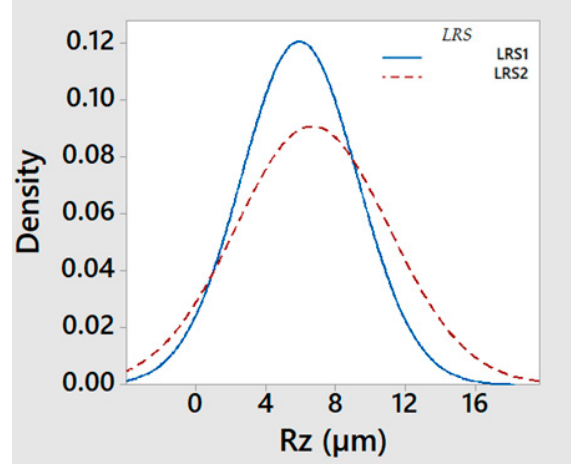

(j)

Figure 5. Normal distribution of $R a(\mu \mathrm{m})$ and $R z(\mu \mathrm{m})$, respectively, with respect to $(\mathbf{a}, \mathbf{b})$ feed rate, $f$ $(\mathrm{mm} / \mathrm{rev}) ;(\mathbf{c}, \mathbf{d})$ spindle speed, $N$ (rpm); (e,f) type of cooling system, $C ;(\mathbf{g}, \mathbf{h})$ location regarding insert, $L R I ;(\mathbf{i}, \mathbf{j})$ location regarding specimen, LRS.

Taking into account that a good behavior of the results is considered when the obtained values are concentrated in the interval $[0.8 \mu \mathrm{m} ; 1.6 \mu \mathrm{m}]$ given by the standard [121], a first approach to the analysis can be made by observing data collected in Tables 6 and 7 and graphics from Figure 5. Thus, it was possible to affirm that $R a$ and $R z$ had a similar behavior for the cutting parameters; however, they were perhaps slightly better for high feed rates $(f=0.10 \mathrm{~mm} / \mathrm{rev})$ and dry machining and they were very similar for both tested values of the spindle speed (perhaps slightly better for low values $N=500 \mathrm{rpm}$ ). Regarding the location relative to the insert, in both magnesium plates, $R a$ and $R z$ were better than in the aluminum plate. Also, when comparing the results of the first and the last magnesium plates, the results were lower for the latter (LRI3). However, LRI1 was considered as better since the surface roughness values were closer to the standard values used in the aeronautic sector (between $0.8 \mu \mathrm{m}$ and $1.6 \mu \mathrm{m}$ ) [121]. Finally, regarding the location relative to the specimen, the results were lower at the entry of the holes than at the exit.

The values from Tables 6 and 7 are plotted in Figures 6 and 7, respectively, revealing possible combinations of parameters that could be used for repairing hybrid parts by re-drilling. Figure 8 plots the $R a$ and $R z$ values obtained in the trials and collected in Table 5. All of them were inside of the usual upper and lower limits given in the chart of conversion relations between $R a$ and $R z$, according to DIN 47 [125]. 


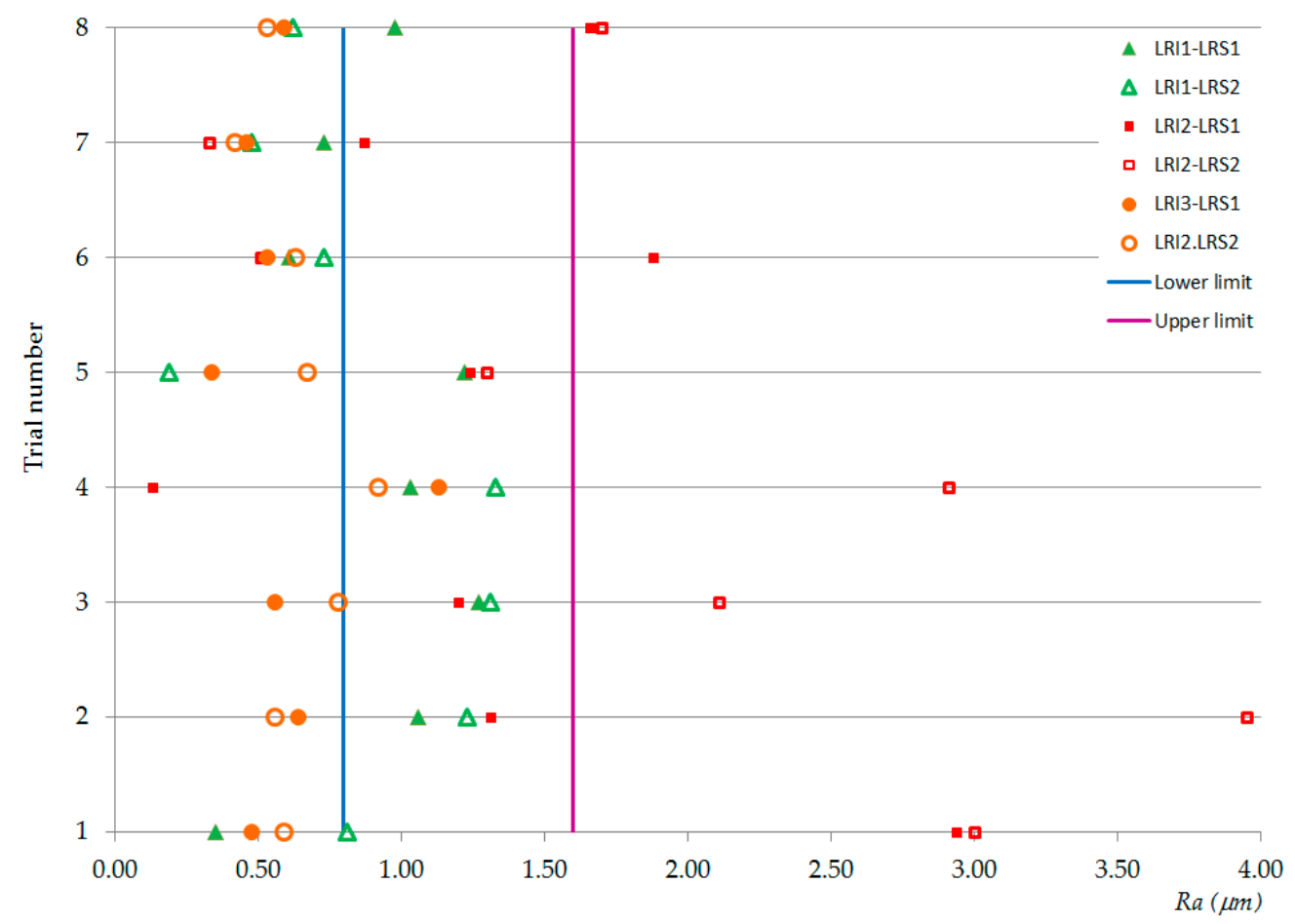

Figure 6. Graphic representation of the $R a$ values.

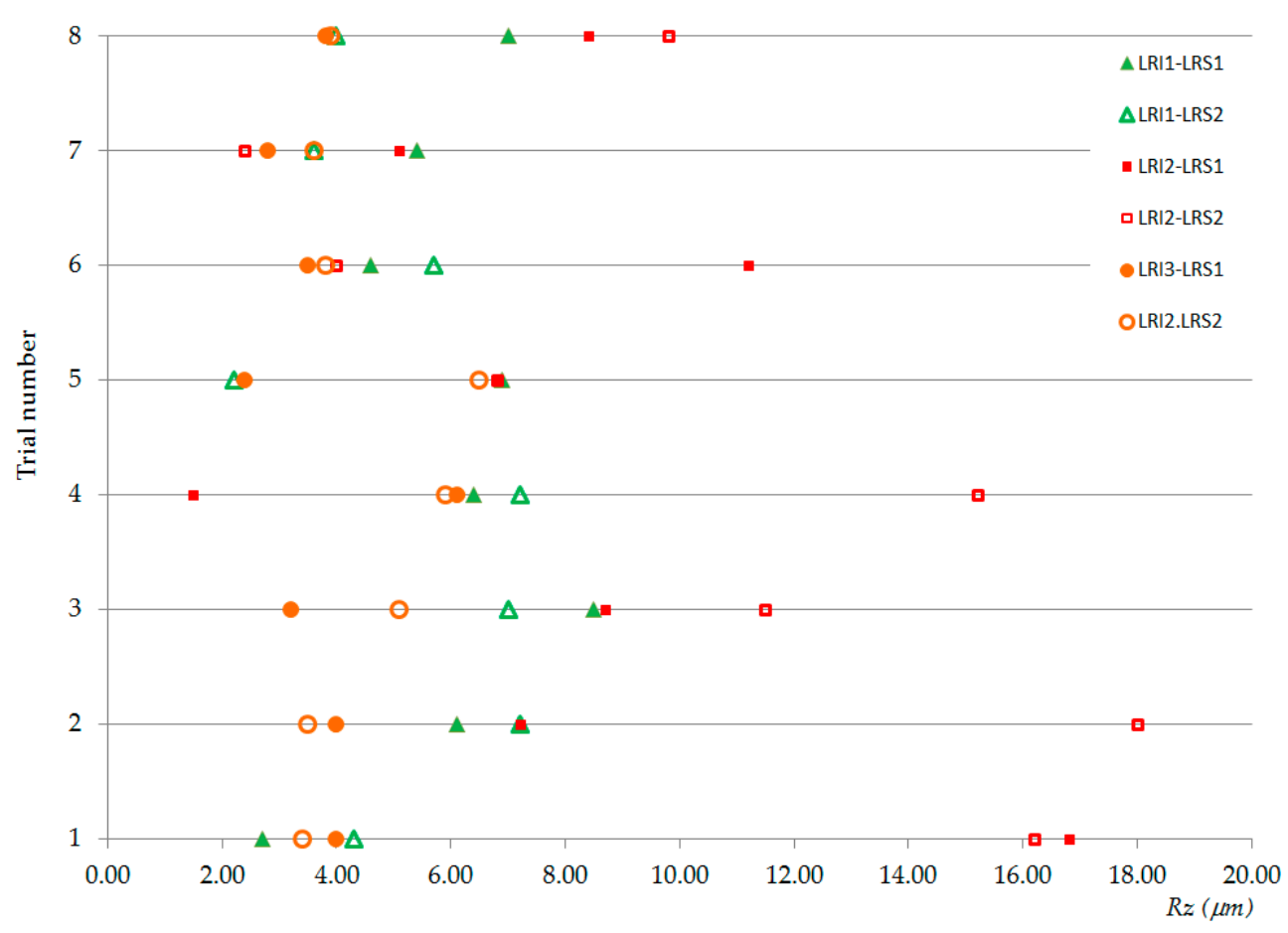

Figure 7. Graphic representation of the $R z$ values. 


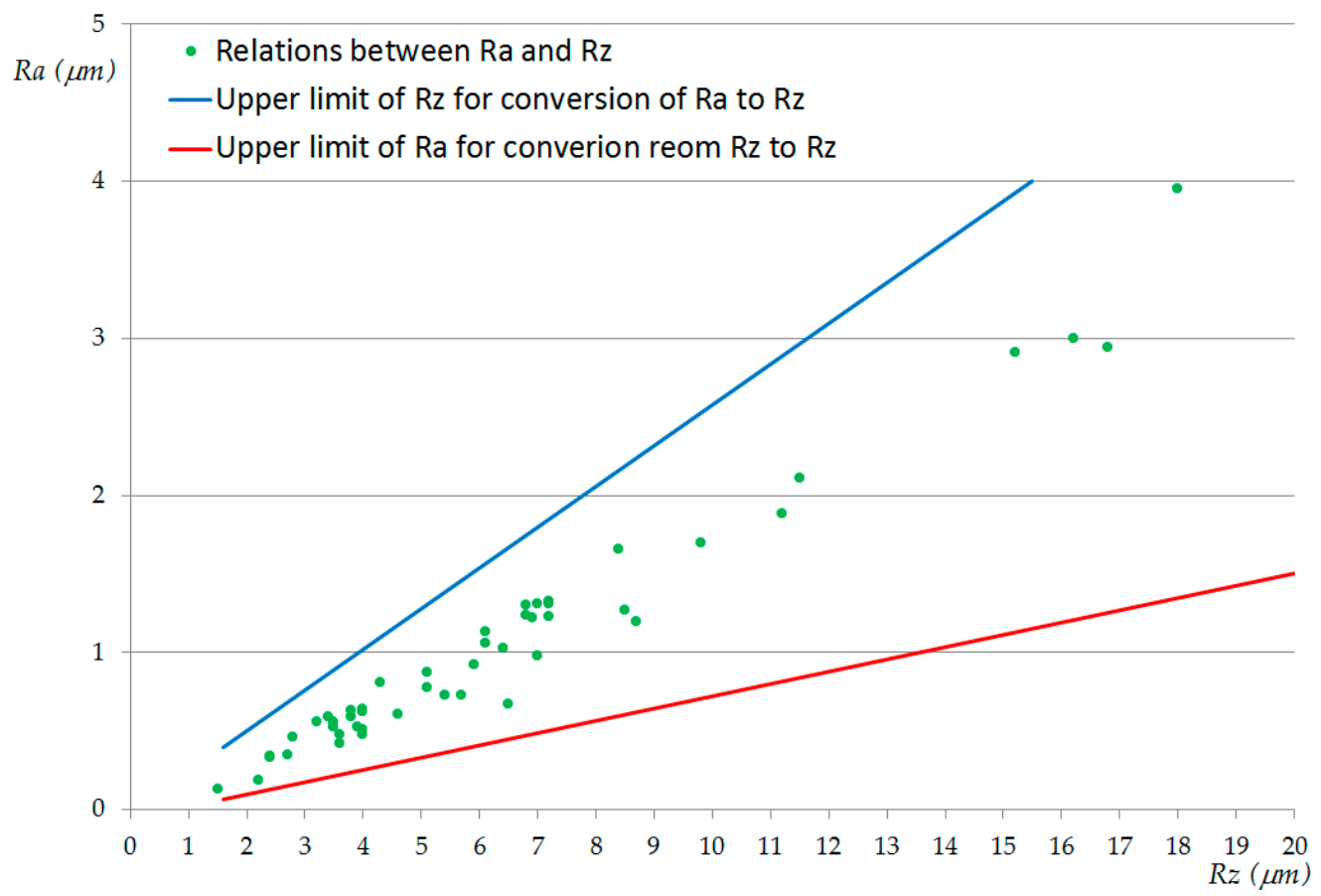

Figure 8. The relationship between $R a$ and $R z$ values.

Observing the $R a$ and $R z$ values in Figures 6 and 7, we see that, for the aluminum plate, the roughness values were higher than for the magnesium plate, especially at the exit of the holes and when using cold compressed air as the cooling system. Therefore, it seems reasonable to select aluminum as the more critical material when establishing the cutting parameters. As the results were better at the entry of the holes, it would perhaps be possible to improve the results by modifying the geometry of hybrid component, for example, by searching for the adequate proportions of the thicknesses of the combined materials. On the other hand, in the second plate of magnesium, most of the surface roughness values (except the obtained one for $f=0.05 \mathrm{~mm} / \mathrm{rev}, N=1200 \mathrm{rpm}$, and $C=$ CCA) were lower than those established in the design requirement standards. Therefore, roughness values might be improved by drilling halfway, turning the hybrid component, and then continuing to drill from the opposite side.

Reviewing the surface roughness values at the entry of the aluminum holes (Table 6 column LRI2, LRS1), it can be seen that test numbers $2,3,5$, and 7 presented values within the range of the values given by the standard $(0.8 \mu \mathrm{m}<R a<1.6 \mu \mathrm{m})$ [121]. Among them, test numbers 2 and 3 were within the same range for the first magnesium plate; test number 5 could be an option if the magnesium plates were about half as thick, since the LRI1 had values within such an interval; test number 7 indicated room for improvement because the roughness value of the aluminum was close to the lower limit of the roughness required in the aeronautic sector $(0.8 \mu \mathrm{m})$. In fact, comparing the roughness values obtained in test number 7 with those from test number 8 , we propose that a new parameter combination is possible by selecting a spindle speed equal to $1000 \mathrm{rpm}$ or near this value; this would also increase the feed speed, decrease the machining time, and, consequently, improve the efficiency of the process.

In addition, an ANOVA was performed to identify the factors that influence the variation of the response variables, $R a$ and $R z$. To apply an ANOVA, it is necessary that the variables meet three conditions: (1) each data group must be independent, (2) the results obtained for each group must follow a normal distribution (although a breach of this assumption is supported when the distribution is symmetric), and (3) the variances of each data group must not differ significantly (homoscedasticity).

Using the data extracted directly from the experiment, the $R a$ and $R z$ values did not follow a normal distribution (Shapiro-Wilk test $p$-value $<0.05$ ). Therefore, the data were processed using logarithmic transformation, maintaining its order but softening the effect of outliers. 
By this approach, normally distributed $\operatorname{Ln} R a$ and $\operatorname{Ln} R z$ values (Shapiro-Wilk test $p$-value $>0.05$ ) were obtained (Figure 9). In addition, the condition of homoscedasticity was also fulfilled (Levene statistic, $p$-value $>0.05$ ), and independent data groups had a similar number of cases (Table 8). In the analysis, interactions up to the third order were considered, and successive iterations were performed until all values were significant. In each iteration, the statistically less significant effect was excluded if it had a $p$-value greater than 0.05. Tables 9 and 10 give the outcome of the first and the last ANOVA over $L n R a$, and Tables 11 and 12 collect the outcome of the first and the last ANOVA over $L n R z$, respectively.

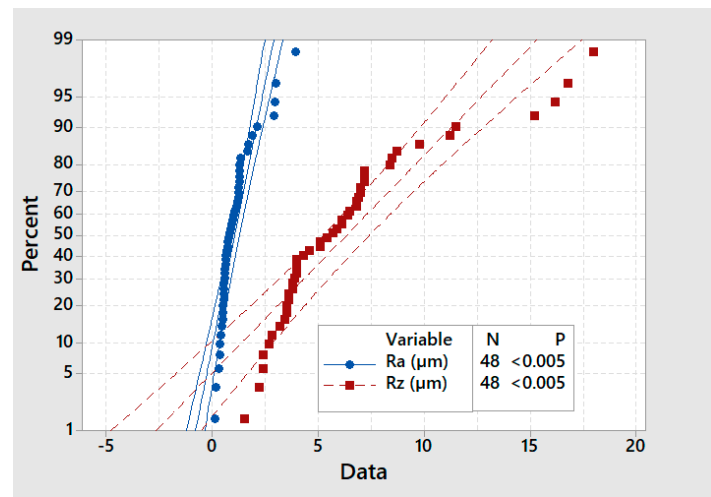

(a)

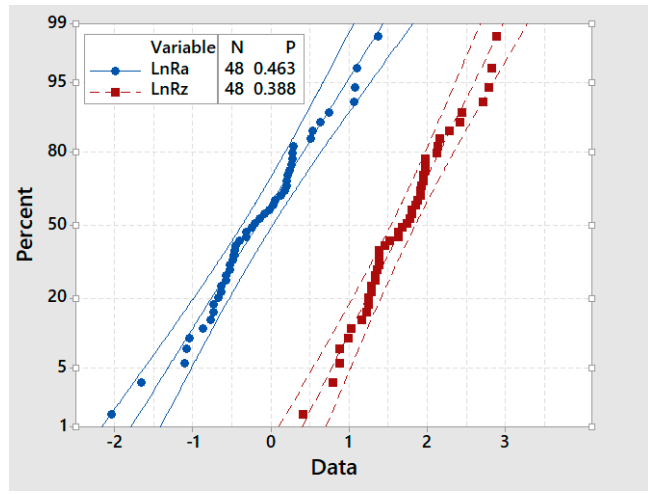

(b)

Figure 9. Probability plots: (a) $R a$ and $\mathrm{Rz}$; (b) LnRa and LnRz.

Table 8. Homogeneity test of variances for factors $f$ and $N$ and response variables $L n R a$ and $L n R z$.

\begin{tabular}{ccccc}
\hline & \multicolumn{2}{c}{$f(\mathrm{~mm} / \mathrm{rev})$} & \multicolumn{2}{c}{$N(\mathrm{rpm})$} \\
\hline & Levene Statistic & Significance & Levene Statistic & Significance \\
\hline$L n R a$ & 0.30 & 0.59 & 0.58 & 0.46 \\
$\operatorname{LnRz}$ & 0.21 & 0.65 & 0.13 & 0.72 \\
\hline
\end{tabular}

Table 9. Outcome of the first iteration for the ANOVA over LnRa.

\begin{tabular}{cccccc}
\hline Source & DF & Sum of Squares & Mean Square & F-value & $p>$ F \\
\hline Corrected Model & 23 & 13.037 & 0.567 & 1.415 & 0.202 \\
Intercept & 1 & 1.486 & 1.486 & 3.709 & 0.066 \\
$L R I$ & 2 & 4.983 & 2.491 & 6.217 & 0.007 \\
$N$ & 1 & 0.306 & 0.306 & 0.764 & 0.391 \\
$f$ & 1 & 0.010 & 0.010 & 0.025 & 0.875 \\
$C$ & 1 & 1.882 & 1.882 & 4.697 & 0.040 \\
$L R I \times N$ & 2 & 0.365 & 0.183 & 0.456 & 0.639 \\
$L R I \times f$ & 2 & 1.766 & 0.883 & 2.203 & 0.132 \\
$L R I \times C$ & 2 & 0.070 & 0.035 & 0.087 & 0.917 \\
$N \times f$ & 1 & 0.002 & 0.002 & 0.006 & 0.938 \\
$N \times C$ & 1 & 0.306 & 0.306 & 0.764 & 0.391 \\
$f \times C$ & 1 & 0.003 & 0.003 & 0.008 & 0.929 \\
$L R I \times N \times f$ & 2 & 0.368 & 0.184 & 0.459 & 0.638 \\
$L R I \times N \times C$ & 2 & 0.801 & 0.401 & 1.000 & 0.383 \\
$L R I \times f \times C$ & 2 & 0.906 & 0.453 & 1.130 & 0.340 \\
$N \times f \times C$ & 1 & 0.576 & 0.576 & 1.437 & 0.242 \\
$L R I \times N \times f \times C$ & 2 & 0.694 & 0.347 & 0.865 & 0.434 \\
Error & 24 & 9.617 & 0.401 & - & - \\
Total & 48 & 24.141 & - & - & - \\
Corrected Total & 47 & 22.654 & - & - & - \\
\hline
\end{tabular}

${ }^{*} \mathrm{DF}$, degrees of freedom. 
Table 10. Outcome of the last iteration for the ANOVA over LnRa.

\begin{tabular}{cccccc}
\hline Source & DF & Sum of Squares & Mean Square & F-value & $p>$ F \\
\hline Corrected Model & 5 & $6.935 \mathrm{a}$ & 1.387 & 3.706 & 0.007 \\
Intercept & 1 & 1.486 & 1.486 & 3.971 & 0.053 \\
LRI & 2 & 4.983 & 2.491 & 6.656 & 0.003 \\
C & 1 & 1.882 & 1.882 & 5.029 & 0.030 \\
Error & 42 & 15.720 & 0.374 & - & - \\
Total & 48 & 24.141 & - & - & - \\
Corrected Total & 47 & 22.654 & - & - & - \\
\hline
\end{tabular}

${ }^{*} \mathrm{DF}$, degrees of freedom.

Table 11. Outcome of the first iteration for the ANOVA over LnRz.

\begin{tabular}{cccccc}
\hline Source & DF & Sum of Squares & Mean Square & F-value & $p>$ F \\
\hline Corrected Model & 23 & $8.726 a$ & 0.379 & 1.600 & 0.130 \\
Intercept & 1 & 137.220 & 137.220 & 578.50 & 0.000 \\
$L R I$ & 2 & 3.673 & 1.836 & 7.742 & 0.003 \\
$C$ & 1 & 0.963 & 0.963 & 4.061 & 0.055 \\
$f$ & 1 & 0.009 & 0.009 & 0.039 & 0.845 \\
$N$ & 1 & 0.150 & 0.150 & 0.633 & 0.434 \\
$L R I \times C$ & 2 & 0.190 & 0.095 & 0.402 & 0.674 \\
$L R I \times f$ & 2 & 1.027 & 0.514 & 2.165 & 0.137 \\
$L R I \times N$ & 2 & 0.172 & 0.086 & 0.363 & 0.699 \\
$C \times f$ & 1 & 0.014 & 0.014 & 0.057 & 0.813 \\
$C \times N$ & 1 & 0.232 & 0.232 & 0.978 & 0.332 \\
$f \times N$ & 1 & 0.011 & 0.011 & 0.048 & 0.828 \\
$L R I \times C \times f$ & 2 & 0.490 & 0.245 & 1.034 & 0.371 \\
$L R I \times C \times N$ & 2 & 0.840 & 0.420 & 1.770 & 0.192 \\
$L R I \times f \times N$ & 2 & 0.381 & 0.190 & 0.803 & 0.460 \\
$C \times f \times N$ & 1 & 0.311 & 0.311 & 1.310 & 0.264 \\
$L R I \times C \times f \times N$ & 2 & 0.263 & 0.131 & 0.553 & 0.582 \\
Error & 24 & 5.693 & 0.237 & & \\
Total & 48 & 151.639 & & & \\
Corrected Total & 47 & 14.419 & & & \\
\hline
\end{tabular}

${ }^{*} \mathrm{DF}$, degrees of freedom.

Table 12. Outcome of the last iteration for the ANOVA over $\operatorname{Ln} R z$.

\begin{tabular}{cccccc}
\hline Source & DF & Sum of Squares & Mean Square & F-value & $p>$ F \\
\hline Corrected Model & 5 & 4.826 & 0.965 & 4.226 & 0.003 \\
Intercept & 1 & 137.22 & 137.220 & 600.78 & 0.000 \\
LRI & 2 & 3.673 & 1.836 & 8.040 & 0.001 \\
C & 1 & 0.963 & 0.963 & 4.217 & 0.046 \\
Error & 42 & 9.593 & 0.228 & & \\
Total & 48 & 151.63 & & & \\
Corrected Total & 47 & 14.419 & &
\end{tabular}

Taking into account the results shown in Tables 10 and 12, we conclude that the most influential factors, in both cases, were the location relative to the insert (LRI) and the type of cooling system $(C)$, and that there were no interactions among factors with influence.

Considering the re-drilling surface roughness variability of hybrid $\mathrm{Mg}-\mathrm{Al}-\mathrm{Mg}$ components explained by the statistically significant effect obtained from the ANOVA, the percentage of variability attributed to each factor is shown in Table 13, and the contribution of each effect was obtained as the percentage of the sum of squares values of each significant effect relative to the sum of squares of all significant effects. 
Table 13. Percentage variability of the statistically significant effects obtained from ANOVA.

\begin{tabular}{ccccc}
\hline \multirow{2}{*}{ Source } & \multicolumn{2}{c}{$\boldsymbol{R a}$} & \multicolumn{2}{c}{$\boldsymbol{R z}$} \\
\cline { 2 - 5 } & Sum of Squares & Variability Percentage & Sum of Squares & Variability Percentage \\
\hline \multirow{2}{*}{$L R I$} & 5.0 & $72.6 \%$ & 3.7 & $79.2 \%$ \\
$C$ & 1.9 & $27.4 \%$ & 1.0 & $20.8 \%$ \\
Total & 6.9 & $100 \%$ & 4.6 & $100 \%$ \\
\hline
\end{tabular}

\section{Conclusions}

This work focused on the maintenance and repair of holes made of hybrid $\mathrm{Mg}-\mathrm{Al}-\mathrm{Mg}$ components by drilling, using two sustainable cooling techniques: dry machining and cold compressed air. The aeronautic and aerospace sectors were selected as relevant applications. In such sectors, the pieces have strict design requirements for surface roughness $(0.8 \mu \mathrm{m}<R a<1.6 \mu \mathrm{m}) . R a$ and $R z$ were taken as response variables. From our analyses, we propose that $R a$ and $R z$ values have similar behaviors and they exhibit the following characteristics:

- They are better for high feed rates and dry machining.

- They are very similar for both tested values of spindle speed, although perhaps slightly better for low values.

- They are, regarding the location relative to the insert, better in both magnesium plates than in the aluminum plate; also, when comparing the results of the first and the last magnesium plate, the results were lower for $L R I 3$, yet the values for LRI1 were considered better since the surface roughness values were closer to the aeronautic industry standard.

- They display, for the location regarding specimen, better behavior at the entry of the holes than at the exit.

- They are higher in the plate of aluminum than in the magnesium one, particularly at the exit of the holes and, in a more pronounced way, using cold compressed air as a cooling system. Therefore, aluminum is considered a more valuable material when selecting the cutting parameters. Also, as the results are better (lower values) at the entry of the holes than at the exit, it will perhaps be possible to improve the results by modifying the geometry of the hybrid component, for example, by searching for the adequate thicknesses among the different combined materials.

- They are lower, in most cases, in the second plate of magnesium than the established standard. Therefore, the process can be influenced by the drilling direction, and it could be improved by drilling halfway, turning the part, and drilling again from the opposite side.

In addition, from the ANOVA analysis, we found that the factors that influence the response variables $R a$ and $R z$ are location relative to the insert and type of cooling system, with percentages of influence of $72.6 \%$ and $27.4 \%$, respectively, for $\mathrm{Ra}$, and $79.2 \%$ and $20.8 \%$, respectively, for $R z$.

With this work, we showed that it is possible to simultaneously repair magnesium-aluminum-magnesium multi-material components and parts made of aluminum and magnesium (separately) but assembled to form a higher component using sustainable cooling systems (dry machining). This approach reduces the time and cost associated with the assembly and disassembly of these types of components during maintenance or repair.

In conclusion, we propose three ways to optimize (or at least improve) the process: (1) using different parameters values (for example, higher values of the spindle speed that increase the efficiency of the process); (2) designing a hybrid component with new proportions of the thicknesses of the materials combined; (3) applying other drilling sequences (e.g., firstly drilling halfway and then turning the part and drilling from the opposite side).

Author Contributions: E.M.R., M.M.M., and D.B. contributed to the conceptualization, methodology, and formal analysis. D.B. performed the investigation. E.M.R. and M.M.M. managed the project resources. E.M.R., M.M.M., and D.B. prepared the original draft of the manuscript. E.M.R., M.M.M., D.B., and J.P.D. reviewed and edited 
the manuscript. E.M.R., M.M.M., D.B., and J.P.D. contributed to data visualization. E.M.R., M.M.M., and J.P.D. supervised the study. E.M.R. and M.M.M. were responsible for the funding acquisition and project administration. All authors read and agreed to the published version of the manuscript.

Funding: This work was partly funded by grants from the Ministerio de Ciencia, Innovación, y Universidades, and the Industrial Engineering School-UNED (RTI2018-102215-B-I00, REF2019-ICF05, and REF2019-ICF08), Spain.

Acknowledgments: The authors thank the Industrial Production and Manufacturing Engineering (IPME) Research Group and the Industrial Engineering School-UNED (Projects REF2019-ICF05 and REF2019-ICF08).

Conflicts of Interest: The authors declare no conflicts of interest.

\section{References}

1. Rubio, E.M.; Blanco, D.; Marín, M.M.; Carou, D. Analysis of the latest trends in hybrid components of lightweight materials for structural uses. In Proceedings of the 8th Manufacturing Engineering Society International Conference 2019 (MESIC 2019), Madrid, Spain, 19-21 June 2019.

2. Lee, D.; Morillo, C.; Oller, S.; Bugeda, G.; Oñate, E. Robust design optimization of advance hybrid (fiber-metal) composite structures. Compos. Struct. 2013, 99, 181-192. [CrossRef]

3. DRL. Innovation Report 2011; Institute of Composites Structures and Adaptative Systems: Braunschweig, Germany, 2011.

4. Ashby, M. Hybrid Materials to Expand the Boundaries of Material-Property Space. J. Am. Ceram. Soc. 2011, 94, 3-14. [CrossRef]

5. Ashby, M.F.; Bréchet, Y.J.M. Design hybrid mate. Acta Mater. 2003, 51, 5801-5821. [CrossRef]

6. Boyer, R.R.; Cotton, J.D.; Mohaghegh, M.; Schafrik, R.E. Materials considerations for aerospace applications. Mrs Bull. 2015, 40, 1055-1066. [CrossRef]

7. Taub, A.I.; Luo, A.A. Advanced lightweight materials and manufacturing processes for automotive applications. Materials considerations for aerospace applications. Mrs Bull. 2015, 40, 1045-1054. [CrossRef]

8. Montemayor, L.; Chernow, V.; Greer, J.R. Materials by design: Using architecture in material design to reach new property spaces. Mrs Bull. 2015, 40, 1122-1129. [CrossRef]

9. Available online: https://www.asoc-aluminio.es/info-aea (accessed on 14 January 2020).

10. Available online: https://www.aluminum.org/ (accessed on 14 January 2020).

11. Berrio, L.F.; Echeverry, M.; Correa, A.A.; Robledo, S.M.; Castaño, J.G.; Echeverría, F. Development of the magnesium alloy industry in Colombia-An opportunity. Dyna 2017, 84, 55-64.

12. Sáenz de Pipaón, J.M. Diseño y Fabricación de Probetas de Componentes Híbridos con Aleaciones de Magnesio para Ensayos de Mecanizado. Ph.D. Thesis, UNED (Universidad Nacional de Educación a Distancia), Madrid, Spain, 2013.

13. Saa, A.J. Estudio Experimental Basado en la Rugosidad Superficial para la Selección de Herramientas y Condiciones de Corte en Operaciones de Refrentado en Seco a Baja Velocidad de Piezas de Magnesio. Ph.D. Thesis, UNED (Universidad Nacional de Educación a Distancia), Madrid, Spain, 2015.

14. Carou, D. Estudio Experimental para Determinar la Influencia de la Refrigeración/Lubricación en la Rugosidad Superficial en el Torneado Intermitente a Baja Velocidad de Piezas de Magnesio. Ph.D. Thesis, UNED (Universidad Nacional de Educación a Distancia), Madrid, Spain, 2013.

15. Dreizin, E.L.; Berman, C.H.; Vicenzi, E.P. Condensed-phase modifications in magnesium particle combustion in air. Combust. Flame 2000, 122, 30-42. [CrossRef]

16. Carou, D.; Rubio, E.M.; Davim, J.P. Analysis of ignition risk in intermittent turning of UNS M11917 magnesium alloy at low cutting speeds based on the chip morphology. Proc. Inst. Mech. Eng. Part B J. Eng. Manuf. 2015, 229, 365-371. [CrossRef]

17. Benedicto, E.; Carou, D.; Rubio, E.M. Technical, Economic and Environmental Review of the Lubrication/Cooling Systems used in Machining Processes. Procedia Eng. 2017, 184, 99-116. [CrossRef]

18. Rubio, E.M.; de Agustina, B.; Marín, M.M.; Bericua, A. Cooling systems based on cold compressed air: A review of the applications in machining processes. Proc. Eng. 2015, 132, 413-418. [CrossRef]

19. Saá, A.J.; Agustina, B.; Marcos, M.; Rubio, E.M. Experimental study of dry turning of UNS A92024-T3 aluminium alloy bars based on surface roughness. In Proceedings of the AIP Conference Proceedings, Alcoy, Spain, 17-19 June 2009; Volume 1181, pp. 151-158. 
20. Agustina, B.; Saá, A.; Marcos, M.; Rubio, E.M. Analysis of the machinability of aluminium alloys UNS A97050-T7 and UNS A92024-T3 during short dry turning tests. In Advanced Materials Research; Trans Tech Publications: Bäch, Switzerland, 2011; Volume 264, pp. 931-936.

21. Agustina, B.; Rubio, E.M. Experimental study of cutting forces during dry turning processes of UNS A92024-T3 aluminium alloys. In Proceedings of the 4th Manufacturing Engineering Society International Conference 2011 (MESIC 2011), Cadiz, Spain, 21-23 September 2011; pp. 1-6.

22. Agustina, B.; Rubio, E.M. Analysis of cutting forces during dry turning processes of UNS A92024-T3 aluminium bars. Adv. Mater. Res. 2012, 498, 25-30. [CrossRef]

23. Agustina, B.; Rubio, E.M.; Sebastian, M.A. Surface roughness model based on force sensors for the prediction of the tool wear. Sensors 2014, 4, 6393-6408. [CrossRef] [PubMed]

24. Arokiadass, R.; Palaniradja, K.; Alagumoorthi, N. Effect of process parameters on surface roughness in end milling of Al/SiCp MMC. Int. J. Eng. Sci. Technol. 2011, 13, 276-284.

25. Rubio, E.M.; Camacho, A.M.; Sánchez, J.M.; Marcos, M. Surface roughness of AA7050 alloy turned bars, analysis of the influence of the length of machining. J. Mater. Process. Technol. 2005, 162, 682-689. [CrossRef]

26. Batista, M.; Sánchez-Carrilero, M.; Rubio, E.M.; Marcos, M. Cutting Speed and Feed Based Analysis of Chip Arrangement in the Dry Horizontal Turning of UNS A92024 Alloy. Ann. DAAAM Proc. 2009, 20,967-968.

27. Bisker, J.; Christman, T.; Allison, T.; Goranson, H.; Landmesser, J.; Minister, A.; Plonski, R. DOE Handbook. In Primer on Spontaneous Heating and Pyrophoricity; U.S. Department of Energy: Washington, DC, USA, 1994; pp. 1-68.

28. Rubio, E.M.; Sáenz de Pipaón, M.J.; Villeta, M.; Sebastián, M.A. Experimental study for improving repair operations of pieces of magnesium UNS M11311 obtained by dry turning. In Proceedings of the 12th CIRP Conference on Modelling of Machining, San Sebastian, Spain, 7-8 May 2009; pp. 819-826.

29. Carou, D.; Rubio, E.M.; Davim, J.P. Discontinuous cutting: Failure mechanisms, tools materials and temperature study-A review. Rev. Adv. Mater. Sci. 2014, 38, 110-124.

30. Rubio, E.M.; Bericua, A.; de Agustina, B.; Marín, M.M. Analysis of the surface roughness of titanium pieces obtained by turning using different cooling systems. In Proceedings of the 12th CIRP Conference on Intelligent Computation in Manufacturing Engineering, Naples, Italy, 18-20 July 2018.

31. Carou, D.; Rubio, E.M.; Agustina, B.; Marín, M.M. Experimental study for effective and sustainable repair and maintenance of bars made of Ti-6Al-4V alloy application to the aeronautic industry. J. Clean. Prod. 2017, 164, 465-475. [CrossRef]

32. Carou, D.; Rubio, E.M.; Davim, J.P. A note on the use of the minimum quantity lubrication (MQL) system in turning. Ind. Lubr. Tribol. 2015, 67, 256-261. [CrossRef]

33. Khan, A.M.; Jamil, M.; Mia, M.; Pimenov, D.Y.; Gasiyarov, V.R.; Gupta, M.K.; He, N.; Khan, A.M. Multi-Objective Optimization for Grinding of AISI D2 Steel with $\mathrm{Al}_{2} \mathrm{O}_{3}$ Wheel under MQL. Materials 2018, 11, 2269. [CrossRef]

34. Mia, M.; Dey, P.R.; Hossain, M.S.; Arafat, M.T.; Asaduzzaman, M.; Shoriat, M.; Tareq, S.M. Taguchi S/N based optimization of machining parameters for surface roughness, tool wear and material removal rate in hard turning under MQL cutting condition. Measurement 2018, 122, 380-391. [CrossRef]

35. Mia, M.; Rifat, A.; Tanvir, M.F.; Gupta, M.K.; Hossain, M.J.; Goswami, A. Multi-objective optimization of chip-tool interaction parameters using Grey-Taguchi method in MQL-assisted turning. Measurement 2018, 129, 156-166. [CrossRef]

36. Mia, M. Mathematical modeling and optimization of MQL assisted end milling characteristics based on RSM and Taguchi method. Measurement 2018, 121, 249-260. [CrossRef]

37. Sharma, A.K.; Tiwari, A.K.; Dixit, A.R. Effects of Minimum Quantity Lubrication (MQL) in machining processes using conventional and nanofluid based cutting fluids: A comprehensive review. J. Clean. Prod. 2016, 127, 1-18. [CrossRef]

38. Singh, G.R.; Gupta, M.; Mia, M.; Sharma, V. Modeling and optimization of tool wear in MQL-assisted milling of Inconel 718 superalloy using evolutionary techniques. Int. J. Adv. Manuf. Technol. 2018, 97, 481-494. [CrossRef]

39. Singh, G.R.; Pruncu, C.I.; Gupta, M.K.; Mia, M.; Khan, A.M.; Jamil, M.; Pimenov, D.Y.; Sen, B.; Sharma, V.S. Investigations of Machining Characteristics in the Upgraded MQL-Assisted Turning of Pure Titanium Alloys Using Evolutionary Algorithms. Materials 2019, 12, 999-1016. [CrossRef] 
40. Maruda, R.; Feldshtein, E.; Legutko, S.; Krolczyk, G. Analysis of Contact Phenomena and Heat Exchange in the Cutting Zone Under Minimum Quantity Cooling Lubrication conditions. Arab. J. Sci. Eng. 2016, 41, 661-668. [CrossRef]

41. Maruda, R.; Krolczyk, G.; Wojciechowski, S.; Zak, K.; Habrat, W.; Nieslony, P. Effects of extreme pressure and anti-wear additives on surface topography and tool wear during MQCL turning of AISI 1045 steel. J. Mech. Sci. Technol. 2018, 32, 1585-1591. [CrossRef]

42. Mia, M.; Morshed, M.S.; Kharshiduzzaman, M.; Razi, M.; Mostafa, M.; Rahman, S.; Ahmad, I.; Hafiz, M.; Kamal, A. Prediction and optimization of surface roughness in minimum quantity coolant lubrication applied turning of high hardness steel. Measurement 2018, 118, 43-51. [CrossRef]

43. Scharf, T.W.; Prasad, S.V. Solid lubricants: A review. J. Mater. Sci. 2013, 48, 511-531. [CrossRef]

44. Nageswara, D.; Vamsi, P. The influence of solid lubricant particle size on machining parameters in turning. Int. J. Mach. Tools Manuf. 2008, 48, 107-111. [CrossRef]

45. Wenlong, S.; Jianxin, D.; Hui, Z.; Pei, Y.; Jun, Z.; Xing, A. Performance of a cemented carbide self-lubricating tool embedded with MoS2 solid lubricants in dry machining. J. Manuf. Process. 2011, 13, 8-15. [CrossRef]

46. Maheshwera, U.; Ratnam, Y.; Reddy, R.; Kumar, S. Measurement and Analysis of Surface Roughness in WS2 Solid Lubricant Assisted Minimum Quantity Lubrication (MQL) Turning of Inconel 718. Procedia CIRP 2016, 40, 138-143.

47. Varma, J.; Patel, C. A review of effect of solid lubricant in hard turning of alloy steel. Int. J. Adv. Res. Technol. 2013, 2, 12-15.

48. Mia, M.; Gupta, M.K.; Lozano, J.A.; Carou, D.; Pimenov, D.Y.; Królczyk, G.; Khan, A.M.; Dhar, N.R. Multi-objective optimization and life cycle assessment of eco-friendly cryogenic N2 assisted turning of Ti-6Al-4V. J. Clean. Prod. 2019, 210, 121-133. [CrossRef]

49. Mia, M. Multi-response optimization of end milling parameters under through-tool cryogenic cooling condition. Measurement 2017, 111, 134-145. [CrossRef]

50. Hong, S.; Broomer, M. Economical and ecological cryogenic machining of AISI 304 austenitic stainless steel. Clean Prod. Process. 2000, 2, 157-166. [CrossRef]

51. Ghosh, R.; Zurecki, Z.; Frey, J.H. Cryogenic Machining with Brittle Tools and Effects on Tool Life. In International Mechanical Engineering Congress and Exposition; ASME: New York, NJ, USA, 2003; pp. 1-9.

52. Islam, A.K.; Mia, M.; Dhar, N.R. Effects of internal cooling by cryogenic on the machinability of hardened steel. Int. J. Adv. Manuf. Technol. 2017, 90,11-20. [CrossRef]

53. Kamata, Y.; Obikawa, T. High speed MQL finish-turning of Inconel 718 with different coated tools. J. Mater. Process. Technol. 2007, 192, 281-286. [CrossRef]

54. Lu, T.; Jawahir, I. Metrics-based Sustainability Evaluation of Cryogenic Machining. Procedia CIRP 2015, 29, 520-525. [CrossRef]

55. Jawahir, I.; Attia, H.; Biermann, D.; Duflou, J.; Klocke, F.; Meyer, D.; Newman, S.; Pusavec, F.; Putz, M.; Rech, J.; et al. Cryogenic manufacturing processes. CIRP Ann. 2016, 65, 713-736. [CrossRef]

56. Sartori, S.; Ghiotti, A.; Bruschi, S. Temperature effects on the Ti6Al4V machinability using cooled gaseous nitrogen in semi-finishing turning. J. Manuf. Process. 2017, 30, 187-194. [CrossRef]

57. Sun, S.; Brandt, M.; Palanisamy, S.; Dargusch, M.S. Effect of cryogenic compressed air on the evolution of cutting force and tool wear during machining of Ti-6Al-4V alloy. J. Mater. Process. Technol. 2015, 221, 243-254. [CrossRef]

58. Shokrani, A.; Dhokia, V.; Newman, S. Environmentally conscious machining of difficult-to-machine materials with regard to cutting fluids. Int. J. Mach. Tools Manuf. 2012, 57, 83-101. [CrossRef]

59. Najiha, M.; Rahman, M.; Yusoff, A. Environmental impacts and hazards associated with metal working fluids and recent advances in the sustainable systems: A review. Renew. Sustain. Energy Rev. 2016, 60, 1008-1031. [CrossRef]

60. Hosseini, A.; Shabgard, M.; Pilehvarian, F. On the feasibility of a reduction in cutting fluid consumption via spray of biodegradable vegetable oil with compressed air in machining Inconel 706. J. Clean. Prod. 2015, 108, 90-103.

61. Hosseini, T.; Shabgard, M.; Pilehvarian, F. Application of liquid nitrogen and spray mode of biodegradable vegetable cutting fluid with compressed air in order to reduce cutting fluid consumption in turning Inconel 740. J. Clean. Prod. 2015, 108, 90-103. 
62. Jamil, M.; Khan, A.; Hegab, H.; Gong, L.; Mia, M.; Gupta, M.; He, N. Effects of hybrid Al2O 3-CNT nanofluids and cryogenic cooling on machining of Ti-6Al-4V. Int. J. Adv. Manuf. Technol. 2019, 102, 3895-3909. [CrossRef]

63. Sen, B.; Mia, M.; Gupta, M.K.; Rahman, M.A.; Mandal, U.K.; Mondal, S.P. Influence of Al2O3 and palm oil-mixed nano-fluid on machining performances of Inconel-690: IF-THEN rules-based FIS model in eco-benign milling. Int. J. Adv. Manuf. Technol. 2019, 103, 3389-3404. [CrossRef]

64. Khan, A.M.; Jamil, M.; Salonitis, K.; Sarfraz, S.; Zhao, W.; He, N.; Mia, M.; Zhao, G. Multi-Objective Optimization of Energy Consumption and Surface Quality in Nanofluid SQCL Assisted Face Milling. Energies 2019, 12, 710-732. [CrossRef]

65. Singh, R.K.; Sharma, A.K.; Dixit, A.R.; Tiwari, A.K.; Pramanik, A.; Mandal, A. Performance evaluation of alumina-graphene hybrid nano-cutting fluid in hard turning. J. Clean. Prod. 2017, 162, 830-845. [CrossRef]

66. Gupta, M.K.; Jamil, M.; Wang, X.; Song, Q.; Liu, Z.; Mia, M.; Hegab, H.; Khan, A.M.; Collado, A.; Pruncu, C.I.; et al. Performance Evaluation of Vegetable Oil-Based Nano-Cutting Fluids in Environmentally Friendly Machining of Inconel-800 Alloy. Materials 2019, 12, 2792-2812. [CrossRef] [PubMed]

67. Mijanovic, K.; Sokovic, M. Ecological aspects of the cutting fluids and its influence on quantifiable parameters of the cutting processes. J. Mater. Process. Technol. 2001, 109, 181-189.

68. Skerlos, S.J.; Hayes, K.F.; Clarens, A.F.; Zhao, F. Current Advances in Sustainable Metalworking Fluids Research. Int. J. Sustain. Manuf. 2008, 1, 180-202. [CrossRef]

69. Erhan, S.; Sharma, B.; Perez, J. Oxidation and low temperature stability of vegetable oil-based lubricants. Ind. Crop. Prod. 2006, 24, 292-299. [CrossRef]

70. Shashidhara, Y.; Jayaram, S. Vegetable oils as a potential cutting fluid-An evolution. Tribol. Int. 2010, 43, 1073-1081. [CrossRef]

71. Lawal, S.; Choudhury, I.; Nukman, Y. Application of vegetable oil-based metalworking fluids in machining ferrous metals-A review. Int. J. Mach. Tools Manuf. 2012, 52, 1-12. [CrossRef]

72. Xavior, M.; Adithan, M. Determining the influence of cutting fluids on tool wear and surface roughness during turning of AISI 304 austenitic stainless steel. J. Mater. Process. Technol. 2009, 209, 900-909. [CrossRef]

73. Gupta, M.; Mia, M.; Singh, G.R.; Pimenov, D.; Sarikaya, M.; Sharma, V. Hybrid cooling-lubrication strategies to improve surface topography and tool wear in sustainable turning of Al 7075-T6 alloy. Int. J. Adv. Manuf. Technol. 2019, 101, 55-69. [CrossRef]

74. Sanchez, J.; Pombo, I.; Alberdi, R.; Izquierdo, B.; Ortega, N.; Plaza, S.; Martinez-Toledano, J. Machining evaluation of a hybrid MQL CO2 grinding technology. J. Clean. Prod. 2010, 18, 1840-1849. [CrossRef]

75. Su, Y.; He, N.; Li, L.; Iqbal, A.; Xiao, M.H.; Xu, S.; Qiu, B.G. Refrigerated cooling air cutting of difficult-to-cut materials. Int. J. Mach. Tools Manuf. 2007, 47, 927-933. [CrossRef]

76. Zhang, C.; Zhang, S.; Yan, X.; Zhang, Q. Effects of internal cooling channel structures on cutting forces and tool life in side milling of $\mathrm{H} 13$ steel under cryogenic minimum quantity lubrication condition. Int. J. Adv. Manuf. Technol. 2016, 83, 975-984. [CrossRef]

77. Sáenz de Pipaón, M.J.; Rubio, E.M.; Villeta, M.; Sebastián, M.A. Influence of cutting conditions and tool coatings on the surface finish of workpieces of magnesium obtained by dry turning. In Proceedings of the 19th International DAAAM Symposium, Trnava, Slovakia, 22-25 October 2008; pp. 604-605.

78. Carou, D.; Rubio, E.M.; Lauro, J.P.; Davim, J.P. Experimental investigation on surface finish during intermittent turning of UNS M11917 magnesium alloy under dry and near dry machining conditions. Measurement 2014, 56, 136-154. [CrossRef]

79. Carou, D.; Rubio, E.M.; Lauro, J.P.; Davim, J.P. Experimental investigation on finish intermittent turning of UNS M11917 magnesium alloy under dry machining. Int. J. Adv. Manuf. Technol. 2014, 75, 1417-1429. [CrossRef]

80. Ozsváth, P.; Szmejkál, A.; Takács, J. Dry milling of magnesium-based hybrid materials. Transp. Eng. 2008, 36, 73-78. [CrossRef]

81. Prakash, S.; Palanikumar, K.; Mercy, J.L.; Nithyalakshmi, S. Evaluation of surface roughness parameters (Ra, $\mathrm{Rz}$ ) in drilling of MDF composite panel using Box-Behnken experimental design (BBD). Int. J. Des. Manuf. Technol. 2011, 5, 52-62.

82. Rubio, E.M.; Valencia, J.L.; Saá, A.J.; Carou, D. Experimental study of the dry facing of magnesium pieces based on the surface roughness. Int. J. Precis. Eng. Manuf. 2013, 14, 995-1001. [CrossRef] 
83. Rubio, E.M.; Villeta, M.; Carou, D.; Saá, A.J. Comparative analysis of sustainable cooling systems in intermittent turning of magnesium pieces. Int. J. Precis. Eng. Manuf. 2014, 15, 929-940. [CrossRef]

84. Rubio, E.M.; Valencia, J.L.; de Agustina, B.; Saá, A.J. Tool selection based on surface roughness in dry facing repair operations of magnesium pieces. Int. J. Mater. Prod. Technol. 2014, 48, 116-134. [CrossRef]

85. Sáenz de Pipaón, J.M.; Rubio, E.M.; Villeta, M.; Sebastián, M.A. Analysis of the chips obtained by dry turning of UNS M11311 magnesium. In Proceedings of the 3rd Manufacturing Engineering Society International Conference 2009, Alcoy, Spain, 17-19 June 2009; pp. 33-38.

86. Sáenz de Pipaón, J.M.; Rubio, E.M.; Villeta, M.; Sebastián, M.A. Selection of the cutting tools and conditions for the low speed turning of bars of magnesium UNS M11311 based on the surface roughness. In Innovative Production Machines and Systems; Whittles Publishing: Cambridge, UK, 2010; pp. 174-179.

87. Villeta, M.; de Agustina, B.; Sáenz de Pipaón, J.M.; Rubio, E.M. Efficient optimisation of machining processes based on technical specifications for surface roughness: Application to magnesium pieces in the aerospace industry. Int. J. Adv. Manuf. Technol. 2012, 60, 1237-1246. [CrossRef]

88. Rubio, E.M.; Valencia, J.L.; Carou, D.; Saá, A.J. Inserts selection for intermittent turning of magnesium pieces. In Applied Mechanics and Materials; Trans Tech Publications: Bäch, Switzerland, 2012; Volume 217, pp. 1581-1591.

89. Rubio, E.M.; Villeta, M.; Saá, A.J.; Carou, D. Analysis of Main Optimization Techniques in Predicting Surface Roughness in Metal Cutting Processes; Trans Tech Publications: Bäch, Switzerland, 2012; Volume 217, pp. 2171-2182.

90. Rubio, E.M.; Villeta, M.; Agustina, B.; Carou, D. Surface roughness analysis of magnesium pieces obtained by intermittent turning. In Materials Science Forum; Trans Tech Publications: Bäch, Switzerland, 2014; Volume 773, pp. 377-391.

91. Carou, D.; Rubio, E.M.; Lauro, C.H.; Davim, J.P. The effect of minimum quantity lubrication in the intermittent turning of magnesium based on vibration signals. Measurement 2016, 94, 338-343. [CrossRef]

92. Carou, D.; Rubio, E.M.; Lauro, C.H.; Brandão, L.C.; Davim, J.P. Study based on sound monitoring as a means for superficial quality control in intermittent turning of magnesium workpieces. Procedia CIRP 2017, 62, 262-268. [CrossRef]

93. Carou, D.; Rubio, E.M.; Davim, J.P. Chapter 5. Machinability of magnesium and its alloys: A review. In Traditional Machining Processes; Springer: Berlin/Heidelberg, Germany, 2015; pp. 133-152.

94. Berzosa, F.; de Agustina, B.; Rubio, E.M.; Davim, J.P. Feasibility Study of Hole Repair and Maintenance Operations by Dry Drilling of Magnesium Alloy UNS M11917 for Aeronautical Components. Metals 2019, 9, 740-755. [CrossRef]

95. Basmac1, G.; Taskin, A.; Koklu, U. Effect of tool path strategies and cooling conditions in pocket machining of AZ91 magnesium alloy. Indian J. Chem. Technol. 2019, 26, 139.

96. Bruschi, S.; Bertolini, R.; Ghiotti, A.; Savio, E.; Guo, W.; Shivpuri, R. Machining-induced surface transformations of magnesium alloys to enhance corrosion resistance in human-like environment. CIRP Ann. 2018, 67, 579-582. [CrossRef]

97. Danilenko, B.D. Selecting the initial cutting parameters in machining magnesium alloys. Russ. Eng. Res. 2009, 29, 316-319. [CrossRef]

98. Giraud, E.; Rossi, F.; Germain, G.; Outeiro, J.C. Constitutive Modelling of AZ31B-O Magnesium Alloy for Cryogenic Machining. Procedia CIRP 2013, 8, 522-527. [CrossRef]

99. Nasr, M.N.A.; Outeiro, J.C. Sensitivity Analysis of Cryogenic Cooling Machining of Magnesium Alloy AZ31B-O. Procedia CIRP 2015, 31, 264-269. [CrossRef]

100. Outeiro, J.C.; Rossi, F.; Fromentin, G.; Poulachon, G.; Germain, G.; Batista, A.C. Process Mechanics and Surface Integrity Induced by Dry and Cryogenic Machining of AZ31B-O Magnesium Alloy. Procedia CIRP 2013, 8, 487-492. [CrossRef]

101. Pimenov, D.; Erdakov, I. ANN Surface Roughness Optimization of AZ61 Magnesium Alloy Finish Turning: Minimum Machining Times at Prime Machining Costs. Materials 2018, 11, 808.

102. Rashid, R.; Sun, S.; Wang, G.; Dargusch, M. Experimental investigation of laser assisted machining of AZ91 magnesium alloy. Int. J. Precis. Eng. Manuf. 2013, 14, 1263-1265. [CrossRef]

103. Salahshoor, M.; Guo, Y.B. Cutting mechanics in high speed dry machining of biomedical magnesium-calcium alloy using internal state variable plasticity model. Int. J. Mach. Tools Manuf. 2011, 51, 579-591. [CrossRef] 
104. Tonshoff, H.; Winkler, J.; Tonshoff, H. The influence of tool coatings in machining of magnesium. Surf. Coat. Technol. 1997, 94, 610-616. [CrossRef]

105. Rubio, E.M.; Sáenz de Pipaón, J.M.; Valencia, J.L.; Villeta, M. Design, Manufacturing and Machining Trials of Magnesium Based Hybrid Parts. In Machining of Light Alloys: Aluminium, Titanium and Magnesium; CRC-Press: Boca Raton, FL, USA, 2018.

106. Rubio, E.M.; Villeta, M.; Valencia, J.L.; Sáenz de Pipaón, J.M. Experimental Study for Improving the Repair of Magnesium-Aluminium Hybrid Parts by Turning Processes. Metals 2018, 8, 59. [CrossRef]

107. Rubio, E.M.; Villeta, M.; Valencia, J.L.; Sáenz de Pipaón, J.M. Cutting Parameter Selection for Efficient and Sustainable Repair of Holes Made in Hybrid Mg-Ti-Mg Component Stacks by Dry Drilling Operations. Materials 2018, 11, 1369. [CrossRef]

108. Rubio, E.M.; Blanco, D.; Marín, M.M.; Saenz de Pipaon, J.M. Analysis of the surface roughness of Mg-Al-Mg hybrid components obtained by drilling using different cooling systems. In Proceedings of the 13th CIRP Conference on Intelligent Computation in Manufacturing Engineering, Naples, Italy, 17-19 July 2019.

109. Sanz, C.; Fuentes, E.; Gonzalo, O.; Bengoetxea, I.; Obermair, F.; Eidenhammer, M. Advances in the ecological machining of magnesium and magnesium-based hybrid parts. Int. J. Mach. Mach. Mater. 2008, 4, 302-319. [CrossRef]

110. Satheesh, J.; Tajamul, P.; Madhusudhan, T.H. Optimal machining conditions for turning of AlSiC Metal Matrix Composites using ANOVA. Int. J. Innov. Res. Sci. Eng. Technol. 2013, 2, 6171-6176.

111. Sokolowsky, J.H.; Szablewski, D.; Kasprzak, W.; Ng, E.G.; Dumitrescu, M. Effect of tool cutter immersion on Al-Si bi-metallic materials in high-speed milling. J. Achiev. Mater. Manuf. Eng. 2006, 17, 15-20.

112. Vilches, F.J.T.; Hurtado, L.S.; Fernandez, F.M.; Bermudo, C. Analysis of the chip geometry in dry machining of aeronautical aluminum alloys. Appl. Sci. 2017, 7, 132. [CrossRef]

113. Rafai, N.H.; Islam, M.N. An investigation into dimensional accuracy and surface finish achievable in dry turning. Mach. Sci. Technol. 2009, 13, 571-589. [CrossRef]

114. Fletcher, D.I.; Kapoor, A.; Steinhoff, K.; Schuleit, N. Theoretical analysis of steady-state texture formation during wear of a bi-material surface. Wear 2001, 251, 1332-1336. [CrossRef]

115. Arokiasamy, S.; Anand Ronald, B. Experimental investigations on the enhancement of mechanical properties of magnesium-based hybrid metal matrix composites through friction stir processing. Int. J. Adv. Manuf. Technol. 2017, 93, 493-503. [CrossRef]

116. Troconis, B.C.R.; Frankel, G.S. Effects of Pretreatments on the Adhesion of Acetoacetate to AA2024-T3 Using the Blister Test. Corrosion 2014, 70, 483-495. [CrossRef]

117. Vicario, I.; Crespo, I.; Plaza, L.M.; Caballero, P.; Idoiaga, I.K. Aluminium Foam and Magnesium Compound Casting Produced by High-Pressure Die Casting. Metals 2016, 6, 24. [CrossRef]

118. Taub, A. Automotive materials: Technology trends and challenges in the 21st century. MRS Bull. 2006, 31, 336-343. [CrossRef]

119. Zhang, L.; Dhupia, J.S.; Wu, M.; Huang, H. A Robotic Drilling End-Effector and Its Sliding Mode Control for the Normal Adjustment. Appl. Sci. 2018, 8, 1892-1910. [CrossRef]

120. Ralph, W.C.; Johnson, W.S.; Toivonen, P.; Makeev, A.; Newman, J.C. Effect of various aircraft production drilling procedures on hole quality. Int. J. Fatigue 2006, 28, 943-950.

121. The American Society of Mechanical Engineers. Surface Texture: Surface Roughness, Waviness and Lay; ASME: New York, NY, USA, 2010.

122. Montgomery, D.C. Design and Analysis of Experiments; John Wiley \& Sons, Inc.: New York, NY, USA, 2005.

123. Available online: https://www.hoffmann-group.com (accessed on 14 January 2020).

124. ISO 4287:1997 Geometrical Product Specifications (GPS)—Surface Texture: Profile Method—Terms, Definitions and Surface Texture Parameters; International Organization for Standardization: Geneva, Switzerland, 1997.

125. Available online: https://www.kometgroup.com/en/komet/komet/ (accessed on 14 January 2020).

(C) 2020 by the authors. Licensee MDPI, Basel, Switzerland. This article is an open access article distributed under the terms and conditions of the Creative Commons Attribution (CC BY) license (http://creativecommons.org/licenses/by/4.0/). 